Seton Hall University eRepository@Seton Hall

Seton Hall University Dissertations and Theses (ETDs)

Seton Hall University Dissertations and Theses

Spring 5-14-2016

\title{
How Variances in Business School Rankings Affect Enrollment Trends and Practices
}

Guillermo A. de Veyga

Seton Hall University, guillermo.deveyga@student.shu.edu

Follow this and additional works at: https://scholarship.shu.edu/dissertations

Part of the Business Administration, Management, and Operations Commons, Educational Leadership Commons, Higher Education Commons, Organizational Behavior and Theory

Commons, and the Other Business Commons

\section{Recommended Citation}

de Veyga, Guillermo A., "How Variances in Business School Rankings Affect Enrollment Trends and Practices" (2016). Seton Hall University Dissertations and Theses (ETDs). 2137.

https://scholarship.shu.edu/dissertations/2137 
How Variances in Business School Rankings Affect Enrollment Trends and Practices

by

Guillermo A. de Veyga

Dissertation Committee

Robert Kelchen, Ph.D., Mentor Gerard Babo, Ed.D., Committee Member

Joseph Stetar, Ph.D., Committee Member

Submitted in partial fulfillment of the requirements for the degree of

Doctor of Philosophy

Seton Hall University

2016 
(C) Copyright by Guillermo A. de Veyga 2016

All Rights Reserved 


\author{
SETON HALL UNIVERSITY \\ COLLEGE OF EDUCATION AND HUMAN SERVICES \\ OFFICE OF GRADUATE STUDIES
}

\title{
APPROVAL FOR SUCCESSFUL DEFENSE
}

Doctoral Candidate, Guillermo A. de Veyga, has successfully defended and made the required modifications to the text of the doctoral dissertation for the $\mathbf{P h . D}$. during this Spring Semester 2016 .

DISSERTATION COMMITTEE

(please sign and date beside your name)

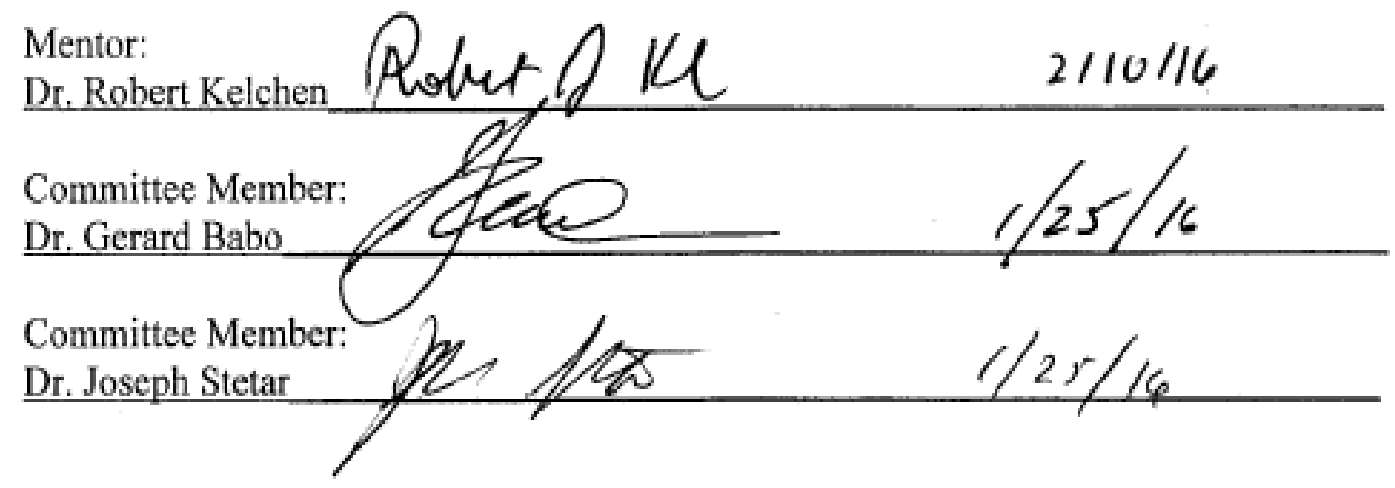

The mentor and any other committee members who wish to review revisions will sign and date this document only when revisions have been completed. Please return this form to the Office of Graduate Studies, where it will be placed in the candidate's file and submit a copy with your final dissertation to be bound as page number two. 


\begin{abstract}
This study examined the effect that variances in the U.S News and World Report rankings have on enrollment trends and practices in both top and not top-25 business schools. The purpose of this study was to determine whether mobility in the rankings was met with a statistically significant response to the research questions presented. While this was not the first study to look at business school rankings and their effect on enrollment trends, it was the first one to look at recent data associated with this phenomena, as well as, the first study to utilize panel data in order to determine the answer to its research questions. The four research questions put forth dealt with enrollment numbers, student quality, acceptance rates and peer assessment scores. The study determined that the research questions are not statistically significant across the board and that one group is more sensitive than the other to variation in the rankings. Possible practical implications for these findings and further research are discussed, as well as, the limitations of the study. Furthermore, a review of all current business school rankings and their methodologies can be found in the study.
\end{abstract}

Keywords: Rankings, U.S. News and World Report, Variances, Enrollment, Business School, Top-25, Selectivity Rate, GPA, GMAT, Peer Assessment Score 


\section{ACKNOWLEDGEMENTS}

It is funny how different people take different paths to a doctorate degree (or anything else they pursue in life for that matter). In my case, although many may have argued that a doctorate degree was merely the inevitable conclusion for my life, I never thought I would have been here 15 years ago. Sometimes it is the smallest things in life that lead us to a path we did not envision walking. I cannot pinpoint what it was that lead me here, but what I can say is that obtaining this degree has been an exercise in perseverance. Although I do not think I ever considered quitting, for years the end-point looked very far away. It was due to some outstanding faculty and the unwavering support of my family and friends that I was able to "triumph."

First, I would like to thank Dr. Robert Kelchen for serving as my advisor throughout the dissertation process. I know there is no way for you to know this, but the praise I have given you to others far exceeds what I can write here; however, I still must praise you for the outstanding assistance you have provided me with. Thank you for helping me narrow down my topic; thank you for sharing your vast of knowledge of institutional rankings with me; thank you for your commitment and availability to always respond; thank you for reviewing draft after draft in order to ensure that a quality product was achieved; and most importantly, thank you for always being there, even when my requests were outlandish, or when I seemed "hard-headed" regarding something. I will forever remember your kindness and will always be grateful.

I also would like to thank Dr. Gerard Babo, who originally helped me think of this topic many years ago. Thank you for serving on the dissertation committee and for your tremendous insight. I could not have done this without you. Next, I want to thank my third committee member, Dr. Joseph Stetar, who was my first professor at Seton Hall (circa 2011) and who also 
taught my last class in the Spring of 2015. Your plethora of knowledge in higher education provided me with a foundation that allowed me to look at this topic from many different angles.

Last but not least, I would like to thank all the (as previously stated) outstanding faculty in the ELMP program who allowed me to grow as a professional (in no particular order) Drs. Finkelstein, Kim, Chen, Walker, Tienken, Stedrak and Iglesias; thank you. Your expertise and willingness to help every step of the way made all the difference.

However, completing a dissertation without family and friends can be a Herculean task, and I can proudly say that I did not need to endure that. To all my family and friends, thank you. Thank you for always bearing with me when you would ask me to get together and do something, but my response would be that I needed to do some writing/research, go to class, etc. To my brother Diego, thank you for always supporting me; someday, although you may need to call me "doctor"; I love you. I want you to know that none of this would have happened without you. Last, but not least, I want to thank my parents, Susana and Juan Antonio, thank you for providing me with the opportunity to be who I am today and study where I did throughout my life. I will always cherish what you have done, especially making significant sacrifices in your own lives in the process; I love you mom and dad. 


\section{IN DEDICATION}

To my loving wife and daughter.

Jess and Maya

Babe (Jess), words cannot express my gratitude for everything you have done. Thank you for always being there and supporting me throughout this journey. Thank you for the proofreading, the thoughts, the ideas, and the patience. This degree is yours as much as mine; I love you.

Maya, everything I have done to this point in life I have done for you. Everything I will continue to do will be for you. I will never complain about the life I have had, but I simply want something better for you; I love you, always. 


\section{TABLE OF CONTENTS}

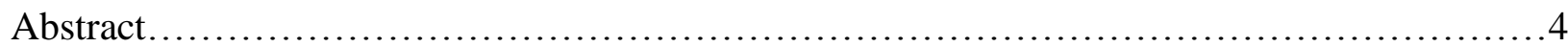

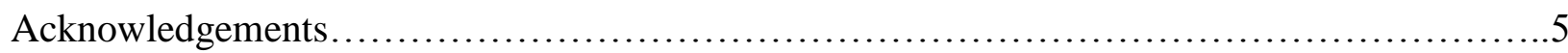

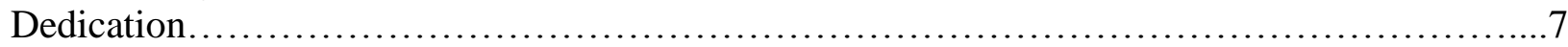

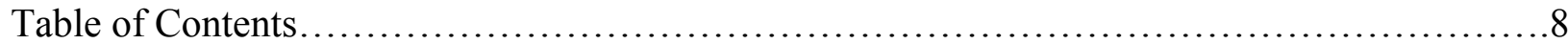

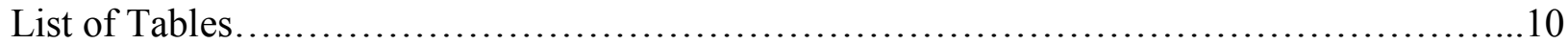

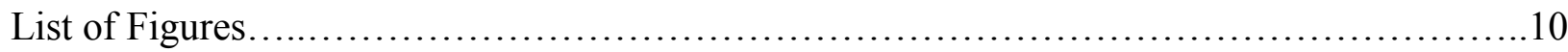

CHAPTER I: INTRODUCTION .....................................................11

Problem Statement.............................................................. 13

Purpose of the Study........................................................... 18

Research Questions.........................................................21

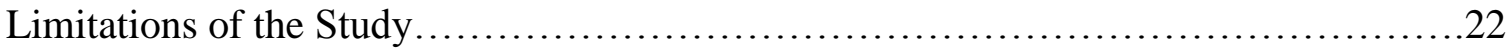

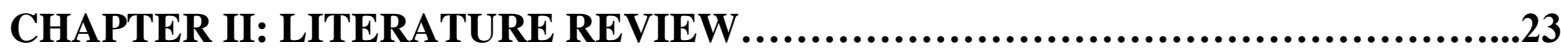

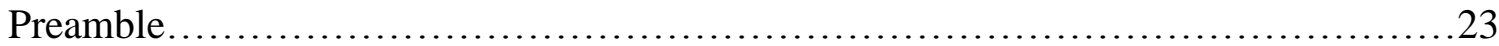

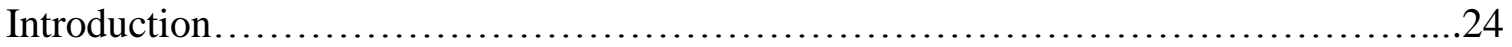

History of the U.S. News Rankings.......................................... 25

History of the Business School Rankings......................................... 28

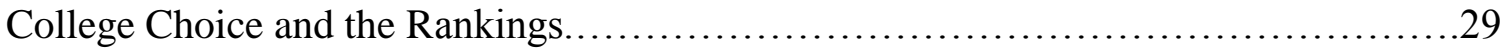

U.S. News and World Report.................................................. 31

U.S. News and the Business School Rankings....................................34

Business Schools and Reputation.................................................... 38

The U.S. News Methodology............................................... 40

Critiques of the Methodologies................................................44

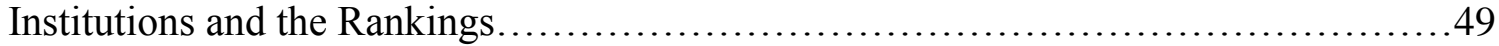

Theories and Alternatives.......................................................... 51

Conclusion and Implications for Research.....................................57

CHAPTER III: METHODOLOGY

Other Business School Rankings' Methodologies................................61

Forbes.............................................................61

Financial Times......................................................... 61

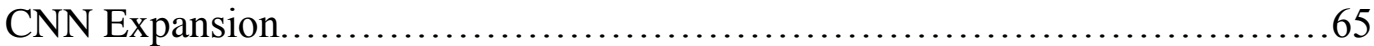

Business Insider.........................................................66

Quacquarelli Symonds................................................67

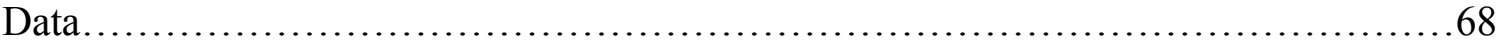

Sample and Variables.......................................................... 70

Data Analysis................................................................. 71 


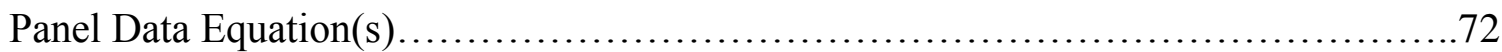

Merging and Cleaning of Data.................................................. 73

Limitations to the Study...................................................... 74

Descriptive Statistics..................................................... 74

Summary............................................................ 77

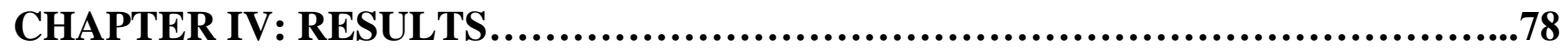

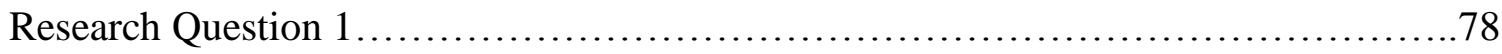

Research Question 2....................................................... 80

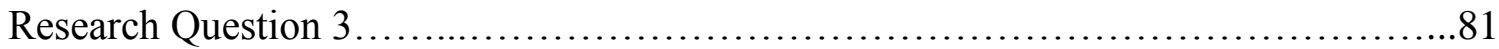

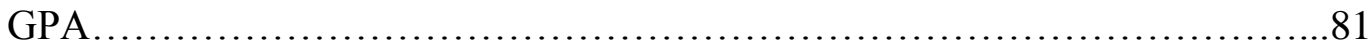

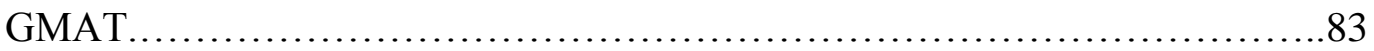

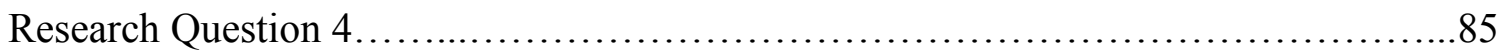

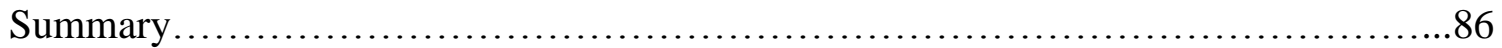

CHAPTER V: CONCLUSION.....................................................87

Summary of Results........................................................ 87

Implications of this Study................................................... 90

Suggestions for Future Research............................................. 93

Conclusion...........................................................94

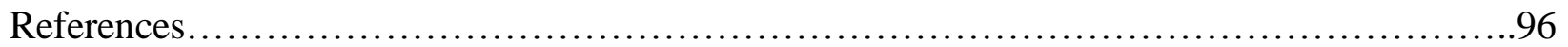




\section{LIST OF TABLES}

Table 1: How the U.S. News Undergraduate Rankings Have Changed Over Time

Table 2: Ranking Indicators of U.S. News and World Report Undergraduate Rankings (for

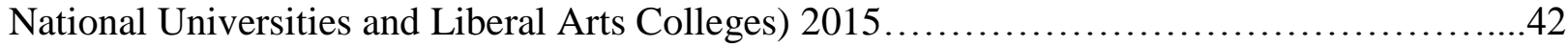

Table 3: Ranking Indicators of U.S. News and World Report for MBA Programs (2015) ......43

Table 4: Business Week 2014 MBA ranking ............................................55

Table 5: Business Week MBA 2014 Ranking: Methodology ...............................56

Table 6: Financial Times 2014 Ranking: Methodology ...............................62

Table 7: The Economist 2014 Ranking: Methodology.................................63

Table 8: America Economia 2014 Ranking: Methodology.................................65

Table 9: CNN Expansion 2014 Ranking: Methodology................................66

Table 10: Descriptive Statistics for 8 Years of Data................................... 75

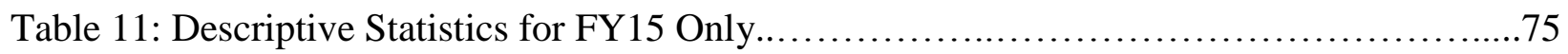

Table 12: Research Question 1 Results ......................................... 78

Table 13: Research Question 2 Results .......................................... 80

Table 14: Research Question 3 (GPA) Results ...................................... 81

Table 15: Research Question 3 (GMAT) Results ...................................83

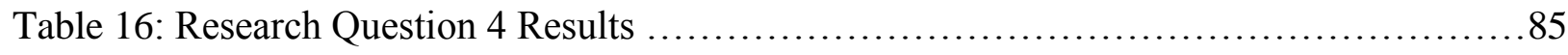

\section{LIST OF FIGURES}

Figure 1: 2015 Ranking: Timeline .69 


\section{Chapter I}

\section{INTRODUCTION}

"Just as democracy, according to Winston Churchill, is the worst form of government except for all the others; quality rankings are the worst device for comparing the quality of colleges and universities, except for all the others" (Webster, 1986, p.6).

Johnson (2006) explained that in today's U.S. society, everything is ranked, compared, ordered, or sorted in some way. There are rankings for almost everything that society engages in: “Top ten tech-savvy cars under 20,000 dollars" (Kelley Blue Book), "Best low cost cell phone plans" (Consumer Reports), "Top ten best cities for retirement” (Bankrate). Consequently, it only follows that, as a society, there is a "need" to know which business school (and institution in general) can be considered "the best." However, it can become a problem when numeric values are used to determine complex issues such as value, quality, or other quantifying intangibles, such as prestige or reputation: It can become even more problematic when all of the variables are reduced to a single numerical value or rank. In addition, the fact that these rankings are handled by for-profit agencies can be concerning to say the least.

Webster (1986) argued that that the obsession towards institutional rankings is not solely because of U.S. society, but instead, he noted that higher education administrators were also to blame for the rise in the reputation of rankings. Webster argued that since higher education institutions (administrators) did not provide enough information about themselves for consumers to make informed decisions, it encouraged others, who were considered "unbiased" to do so for them. In fact, Richard Beeman (as cited in Dearden, Grewal \& Lilien, 2014), the Dean of the 
College of Arts and Sciences at the University of Pennsylvania, in a letter to the New York Times (September 17, 2002) stated, “...I breathed a sigh of relief when my university continued to appear in the U.S. News top 10" (p.3). This goes to show the kind of power that the U.S. News rankings can exert over some administrators, and the relief that comes when they are able to "maintain their position" from year to year.

Still, institutional rankings can be beneficial, since they allow stakeholders to look at institutions of higher education and compare the inputs and outputs, as well as the outcomes. In some cases, rankings may even provide people with the ability to disaggregate data to a departmental level so that individuals can make actual comparisons amongst institutions to answer specific questions (Usher, 2012). For example, rankings can help an individual determine which school may be best for the course of study he or she wishes to pursue.

Rankings can also provide for institutions and their stakeholders to battle for world-class excellence (Hazelkorn, 2011). Since higher education is viewed as critical to the competitiveness of a society and an individual's opportunity for advancement, it would follow that the quality and status of an institution would be important to measure (Hazelkorn, 2009b). In fact, for decades, university rankings have been the main source of institutional performance (Pusser \& Marginson, 2013). Students and parents alike look at them as a guide to help them simply answer a much more complicated question: What college is best for them?

As a result, the rankings for universities and business schools have become a measure of quality, and therefore status by many (Bowman \& Bastedo, 2009; Karabel 2005; McDonough, Antonio, Walpole, \& Perez, 1998; Stevens 2007); consequently, attending a specific university which is high in rank, may very well portray a cachet of which an individual is proud. Recently, the United States Department of Education (ED) had a number of organizations help with public 
statistical data (for analysis), but their goal was never to develop or define institutional rankings (Staff, 2014). The plan, using the Post-Secondary Institution Ratings System, was devised to come up with college ratings. It was hoped that these ratings would provide a public rating of all undergraduate colleges and universities in the US. However, there were many questions surrounding the initiative, especially surrounding the buy-in (and potential backlash) that could occur from institutions that would have been negatively impacted by the data points selected by the scorecard: such as net price and borrowing costs, graduation rates, default rates, average earnings of graduates. Therefore, the initiative was abandoned (The White House, 2014).

A cause of concern for some is that for years the American higher education system has been trying to identify a valid methodology that measures institutional performance (e.g. President Obama's College Scorecard). But absent it, or at least a consensus for the most reliable measure, many private entities have taken it upon themselves to come up with what they believe are the most valid measures for rating and ranking institutional effectiveness, efficiency, or quality. Absent a consensual ranking system, institution leaders have been using ranking publications to attempt to measure their performance, and thus, benchmark themselves against peer and competitor institutions (Meredith, 2004). The most popular of these rankings is that which appears in U.S. News (Altbach, 2012). "Although the media often seek to position their rankings as evaluations of quality, empirical tests of such rankings show that they tend to be rather "noisy" and inconsistent indicators of quality" (Rindova, Williamson, Petkova, \& Sever, 2005, p.10).

\section{Problem Statement}

Despite the claim by many academic institutions that they pay no attention to the U.S. News rankings, they actually do (Ehrenberg, 2005). In fact, there is extensive literature that has 
shown that rankings actually affect the behavioral trends at an institution. In order to increase (or maintain) their position in the rankings, institutions have been caught in many questionable practices that have affected not only other institutions, but also potential students (Golden, 2001a; Thompson, 2000). These practices have ranged from reporting false data to leading-on potential students in hopes that they would apply, in order to augment their selectivity ratio.

Still, students look at these rankings in order to make decisions about what school or graduate school to attend (Bastedo \& Bowman, 2009; Hazelkorn, 2007). Nevertheless, while the research regarding the impact of rankings on a student's choice is not definitive, it is quite strong. Mathewson (2015) stated that in a survey by Chegg, researchers found that $77 \%$ of students reported college rankings as important in their enrollment decisions; however, this number dropped significantly when targeting students from low socio-economic status. Still, $40 \%$ of all U.S. students have been found to use magazine rankings in one way or another (Hazelkorn, 2007). From an institutional standpoint, this signifies a problem, since there can be a disconnect between the amount of effort an institution devotes to its position in the rankings and the yield that it can bring as pertains to student enrollment and school selection.

There have been many studies of undergraduate students and their responses to rankings (Bastedo \& Bowman, 2010, 2011; Bowman \& Bastedo, 2009; Dearden, Grewal, \& Lilien 2014; Espeland \& Sauder, 2007). However, there have not been many studies that have dealt with graduate schools. And even fewer that have dealt with business schools (MBAs in particular). This is problematic because the MBA has become the most popular postgraduate degree in the US (Byrne, 2014a). In 2012, based on figures from the Department of Education, MBA graduates made up $25.4 \%$ of all graduating master's students. This figure is up from $11.2 \%$ in $1971,19.1 \%$ in 1981, and $24.6 \%$ in 2002 (Vaccaro, 2014). This is the first time in history that 
advanced degrees in education have surrendered the top position as the most popular degree in the United States (Vaccaro, 2014). Murray (2010) estimated that in 2009 there were 272,219 students enrolled in MBA programs in the US annually, and this was a conservative estimate.

The increasing attractiveness of the MBA degree has to do with two main factors: a widespread acceptance by employers, and an almost assured return-on-investment of the degree (Byrne, 2014a). Investments made in MBA degrees are often driven by the belief that they will pay off, despite the loans students may have taken out to pay for the degree. Dean Srilata Zaheer (as cited in Byrne, 2014a), from the Carlson School of Management (at the University of Minnesota), stated that, “A business degree remains one of the most predictable paths to success and financial stability, and can provide the "proverbial leg up" from relative poverty to great accomplishment and wealth" (p.2). Dean Paul Danos (as cited in Byrne, 2014a), from the Tuck School of Business (at Dartmouth University), explained that, "business education in general, but especially the great MBA programs, have adapted to the changing needs of companies and organizations better than anyone" (p.3).

Ortmans (2015) showed that age is a factor regarding when people go for their MBAs. Nevertheless, his study found that participants who were 24 or younger when they started their degree saw their salaries increase by $\$ 69,000$; up $145 \%$ from their pre-MBA salaries. Those who were 27 or 28 when they started their MBA program saw their salaries increase by $\$ 67,000$; doubling their pre-MBA salaries. And those who were 31 or above when they began a program saw their salaries increase by $\$ 56,000$ : accounting for an increase of $70 \%$ from their pre-MBA salaries (Ortmans, 2015).

According to the Graduate Management Admission Council (GMAC, as cited in Vaccaro, 2014), between 2010 and 2013, 90\% of business school alumni identified their business 
school education as having good to outstanding value. Also, the survey showed that $66 \%$ of alumni stated that their education was financially rewarding, and $26 \%$ of alumni reported that their expectations for recouping their financial investment were exceeded, while $53 \%$ said their expectations for return-on-investment were met. These results are impressive when one factors in that the alumni, who were most likely to be satisfied with their MBA degrees, were not included in the survey. GMAC's survey had barely any participants who attended from Harvard, Stanford, or Wharton and had none from Chicago Booth, Northwestern University's Kellogg School of Management, MIT Sloan, Columbia Business School, or Dartmouth’s Tuck School of Business. In fact, only 3 institutions in the top 20 were included in the survey (Byrne, 2014b). Having looked at all of this information, one can see how important MBA degrees have become, and how research has not particularly focused on this area specifically, but in the undergraduate population instead. Considering the number of MBA programs and students enrolled in them every year, the idea of measuring their reputation and quality becomes increasingly important.

Hall (1992) stated that one of the most important intangible assets an organization can possess is reputation. This becomes particularly true if the product the institution sells is difficult to assess with regards to its quality and performance and operates within a global market, as is the case of the U.S. business schools (Argenti, 2000; Safon, 2012). Snider (2015) stated that according to a survey from the Graduate Management Admission Council (GMAC) more than half of prospective MBA students from around the world desired to study in a country that was not their own. With this in mind, the US remains a top choice, with $66 \%$ of students hoping to gain admission to an American institution. At the University of California, Riverside, $75 \%$ of the MBA class is from abroad. At Syracuse University, this number is $70 \%$ (Snider, 2015). 
Still, companies such as U.S. News have been preparing rankings that put many of these intangibles in a concrete form. Therefore, they do not need to determine what makes a better or a worse MBA program, but instead they create their own set of criteria to determine which program, in their opinion, are the better business schools. "In little more than a decade, the rankings by these magazines have come to dominate many business schools' sense-making and action-taking efforts and, perhaps most notably, their focus on the fledgling concept of reputation management" (Corley \& Gioia, 1999, p. 319)

At times, prospective MBA students may base their decisions as to which business school to attend on which rankings they may have read (such as U.S. News, Business Week, Forbes, or The Economist). Safon (2012) used Bruce Keith's argument from 2001 to explain that reputation is an outcome of the achievements of the academic institutions. Safon expanded on this by explaining that reputation at the business school level is mainly driven by a combination of three factors: size, student quality, and media rankings.

Ray and Jeon (2008) diminished the concept of value added post business school because they argued using empirical data that most top-rated schools only admit students with high GMAT scores; therefore, most graduates are preselected for a successful post-MBA career, and thus the extent of value added post-business school can be broadly overstated. As of 2012, graduates with no experience (less than 3 years) had a median pay of $\$ 53,900$, which represents a 4.6\% decrease since 2007-08, according to an analysis conducted for The Wall Street Journal by PayScale.com. According to the Seattle based consulting firm, pay has fallen for the graduates of $62 \%$ of the 186 schools examined (Simon, 2013). However, one can argue that during a depression falling pay rates are expected. But as outlined by Simon, what can truly be extracted from these numbers is that being an MBA graduate, with little experience or from a less 
recognized program does not remunerate an individual in the way he or she expects. The employers who are willing to pay top dollar for graduates often do not recruit far down the "prestige ladder" or far down the rankings ladder (Ray \& Jeon, 2008). Media rankings have become an important factor in determining the reputations of business schools (Gioia \& Corley, 2002; Martins, 1998).

Affiliations by employers with highly ranked institutions tends to augment prominence because such affiliations allow stakeholders to assume that the "high-status actors, who are believed to be well informed, have evaluated the organization positively" (Gioia \& Corley, 2002; p.11; Stuart, 2000). Reputation supposedly reduces stakeholder uncertainty about the value of their investments (and the value of future exchanges); therefore, a more favorable reputation is likely to entice buyers to pay a premium for the services of these institutions, or even employers' services (Ray \& Jeon, 2008). Both prominence and perceived quality reduce buyer uncertainty, even if it is through the "faux belief of quality" (Rindova et al., 2005). Either way, they are both likely to have a positive effect on the prices that customers are willing to pay because they increase a customer's confidence in the quality of the goods of an organization, or, in this case, a service. For example, buyers may be willing to pay premium prices for the products of prominent organizations because acquiring such products might enhance their images with their own customers (Podolny, 1994).

\section{Purpose of the Study}

As mentioned previously, there is extensive literature regarding college rankings, student choice, and enrollment trends; yet, the vast majority of articles address undergraduate institutions and first-time students. There is evidence that variances in the U.S. News rankings 
has impacted enrollment trends (i.e. enrollment at an institution, yield, selectivity factor, mean SAT score, mean high school GPA) (Luca \& Smith, 2013; Monks \& Ehrenberg, 1999a,b); nevertheless, the extent to which this has been studied with regard to business schools is limited. Luca and Smith (2013) have specifically emphasized the impact of the U.S. News rankings on applications; however, their study is based on undergraduate rankings, and again, the impact on business schools cannot be explained. The data used in the study by Monks and Ehrenberg is over 15 years old and was calculated by using a different method than the one I intend to use. And again, it is related to undergraduate schools only.

As there has been an increase in exposure to and the popularity of the MBA degree, the popularity of the business school rankings has also increased. Currently, there are nine different business school rankings in the US (U.S. News, Business Week, Forbes, the Financial Times, the Economist, America Economia, CNN Expansion, Business Insider, and the Quacquarelli Symonds Ranking). This represents an increase of $450 \%$ compared to 1990, when only U.S. News and Business Week existed.

Therefore, if rankings are tied to the prestige of an institution and prestige has an impact on a student's decision to attend a particular business school, then it can be hypothesized that as institutional rankings vary, other variables that are tied to rankings will also be impacted. These variables may be correlated with the applicant pool, such as a student's undergraduate grade point average or Graduate Management Admission Test (GMAT) score. Or, these variables might not have to do with the students themselves, but with the institution and how it deals with its applicant pool. Is it admitting the same number of students while keeping the standards for admissions? Or, in order to admit the same number of students, does the institution reach further down into its applicant pool? What does this do to the acceptance rate of a particular institution? 
Does the institution choose to admit fewer students and uphold academic standards? Or, does it favor enrollment numbers? This is important because for an institution to be able to maintain its position in the rankings, it may (or not) have to operate in certain ways.

This study examined one set of rankings by U.S News and World Report, and how variances in the rankings from year to year impacted (or not) enrollment trends and practices in these institutions. The reason for picking U.S. News over any other set of rankings is that, as Ehrenberg (2003) stated, U.S. News' annual rankings are seen as the gold standard of the ranking business.

In this study I explored the change in the number of full-time enrolled students year over year and compared that number with the acceptance rate / the selectivity rate, the mean GPA and GMAT scores of the student population, and the peer evaluations scores these institutions received, all while the rankings of the institutions were examined. Therefore, the question, Will there be a correlation between the variances in the rankings (over time) and other (enrollmentspecific) actions taken by the institution, was examined. While an institution may not necessarily care about a set of rankings (such as those by U.S. News), this does not mean that the institution does not care about the impact that these rankings will have on enrollment.

This study examined the differences between top-25 and non-top 25 business schools, their interaction effect, and different responses to the research questions, since these groups may react to the rankings differently. The reasoning for selecting the top- 25 schools is that U.S. News did print a magazine edition of the rankings, but this has not happened since 2010 . The print edition published a different number of top universities on its first page, but this was often around 45 schools, depending on how many could fit on the page (the number was not consistent from year to year). Since then, its online publication only lists the top-25 business schools on its 
first page. Therefore, the reader must go to the next page to see the next grouping; making the top-25 the default setting.

\section{Research Questions}

1 - Is there a relationship between a one-unit change in the rankings (over time) and the enrollment at a specific institution?

2 - As the ranking of a specific business school varies, does the acceptance ratio / selectivity rate of the business school change?

3 - Has the quality of the students, as measured by their GPA and GMAT scores, changed in response to a one-unit change in the rankings?

4 - Have the attitudes of others towards the business school, as measured by a change in the peer assessment score that these institutions receive year over year, changed as a result of the one-unit variation in the rankings?

Should this study not offer the results an individual anticipates, then the validity of this specific set of rankings, as it pertains to enrollment trends, could be questioned, since the argument to follow will be that variance in the rankings does not affect neither enrollment numbers nor institutional yield (or the characteristics of the incoming class), and therefore, one can question the validity of the rankings (from an enrollment perspective), as well as previous literature on the subject.

Having obtained the last 8 years of rankings data from U.S. News, the purpose of this study was to utilize cross-sectional time series data (panel data) study to analyze the relationship between the rankings in U.S. News and the enrollment trends of the ranked institution. 
This study can be significant because of the potential implications that it may have on three different constituencies: students, researchers and higher education practitioners. Students will be able to understand whether rankings have been somewhat manipulated by the institution, or whether they actually show a true rank, as they continue to utilize them. Researchers will be able to utilize the data and findings from the study for further research especially as it pertains to areas of their own interest. Higher education practitioners will be able to further validate preconceived notions regarding the rankings, or develop new ideas regarding them, and as such, create policies.

\section{Limitations of the Study}

U.S. News is considered to be one of the major sources for MBA rankings (Dichev, 1999; Pleggenkuhle-Miles, Khoury, Deeds, Markoczy, 2013); hence, it was the set of rankings that I chose to focus on in this study. However, a limitation of this study is that only one set of rankings was considered, and students may have used a different set of rankings. Moreover, the data set that was used was limited to the last 8 years. Furthermore, the data utilized by U.S. News is self-reported, so it could not be verified.

In addition, much like Luca and Smith (2013), I was limited in that I did not observe how students learned about the U.S. News rankings. While students possibly read U.S. News, it is clear that institutions used rankings in advertisements and as a marketing tool. This, although it may be a non-factor when it comes to applications, raises the question of what is actually causing the effect and, as such, I was unable to make the distinction. Future research could investigate this question. 


\section{Chapter II}

\section{LITERATURE REVIEW}

\section{Preamble}

This chapter looks at some of the prominent literature written in regard to both business school and undergraduate rankings, since they are correlated, in order to understand some of the concerns that have been addressed over the years. It is key to remember that: "U.S. News undergraduate rankings are almost identical in popularity and in methodology to the business school rankings as they pertain to the admissions outcomes and pricing policies of the undergraduate programs ranked" (Bednowitz, 2000, p.5). Still, because the majority of the literature on the topic has been written about undergraduate rankings, this chapter reviews the literature and its conclusions and then transitions to the literature dealing with business school rankings specifically.

In recent years, more and more university rankings have appeared in magazines, institutes, or external organizations here in the United States and in the rest of the world (Institute for Higher Education Policy, 2007). While the rankings published in U.S. News remain the most prominent, the increased number of rankings that have arisen (Business Week, Forbes, the Financial Times, the Economist, etc.), continue to absorb market share from U.S. News (Bastedo \& Bowman, 2010).

It should be noted that when trying to rank higher education institutions, prestige is one of the most important factors in determining organizational quality, and the U.S. News rankings are the most prominent assessment of said quality (Bowman \& Bastedo, 2009). As Bastedo and Bowman (2010) have stated, one of the reasons why students have often embraced the U.S. 
News rankings has to do with their formal structures, and how these create a somewhat clear stratification of the colleges. This clear and concise stratification defines who is elite and who is not, which is a top school and which is not, what constitutes a top business school and what does not. In higher education, academic stratification is seen as a signal of legitimacy to policymakers, constituencies, stakeholders, and the public in general (Bastedo \& Gumport, 2003; Gumport \& Bastedo, 2001).

The purpose of this chapter is to identify the findings of past research and the possible trends for future research. All the reviewed literature seems to indicate that rankings are here to stay, and that there is a certain inevitability to them; therefore, it does not seem to be the right approach to try to banish all rankings. Instead, different researchers have different approaches based on where they feel the deficiencies of these rankings may fall.

\section{Introduction}

Rankings are symptomatic, but also help accelerate the so-called reputation race (Ehrenberg, 2002). Although an argument can be made that the field of higher education has always been competitive, "rankings make perceptions of prestige and quality explicit" (Freid, 2005, p. 17). "The reputation and the prestige of elite colleges are largely due to their selectivity - having the best students and the best faculty" (Van Vught, 2008, p. 168). Due to an increase in the number of institutions and students and the more pronounced link between attending a prestigious institution and career and salary benefits, a "higher education arms war" has emerged (Hazelkorn, 2011).

The research on rankings is best summarized by Bastedo and Bowman (2010), who noted that the majority of the research in the topic can be categorized in two major areas: making sense 
what type of effect rankings have on student behavior, especially as it pertains to college selection and choice, and understanding the impact rankings can have on organizational identity and change. Hazelkorn (2011) instead chose to differentiate the literature on rankings into methodological concerns: which deal with all the flaws and issues found in the rankings, and the theoretical understanding: which deals with the impact the rankings have on students and organizations.

Regardless of which differentiation of the literature one chooses, any formulation of the rankings needs to have three key factors: (a) students, (b) universities, and (c) ranking publications. These rankings are developed and maintained by private, for-profit magazines or publications, which in turn must balance two potentially juxtaposing ideas: (a) the ability and willingness to provide students with the most accurate information to help them decide what business school and/or college to attend, and (b) the ability to continuously maximize their shareholder's revenue (or bluntly put, to increase the revenues of the publication) (Dearden et al., 2014).

\section{History of the U.S. News Rankings}

The history of ranking institutions of higher education is a practice that dates back to the 1870s, when rankings were created with the goal of informing higher education scholars, professionals, and government officials (Stuart, 1995). The concept of ranking institutions did not gain mass appeal until approximately 1983, almost one century after they first appeared, when U.S. News, by surveying university presidents, published its first rankings of undergraduate academic institutions. At that point, U.S. News identified the top 10 colleges in four areas: national universities, national liberal arts colleges, regional universities, and regional 
liberal arts colleges. These categories were based on the 1976 Carnegie Classification of Institutions of Higher Education. But it was not until 1987 when U.S. News adopted its current multidimensional methodology. By then, U.S. News expanded the selection of schools to include the top-25 in their National University and National Liberal Arts College categories. In 1988, the ranking was expanded to include the top-25 colleges in all four categories. By 1990, all colleges and universities were included in the rankings (Jin \& Whalley, 2007). Come 1998, U.S. News expanded its rankings to the top-50 universities. In 2004, U.S. News further expanded its categories to include: national doctoral universities, regional master's universities, and colleges (Grewal, Dearden, \& Llilien, 2012). Currently, there are rankings for national doctoral universities, liberal arts colleges, graduate programs in six different categories (business, law, nursing, education, medicine, and engineering), community colleges, online programs (seven different categories), high schools (broken down into national and state), global rankings (split into six different realms), and even countries. "In a relatively short period of time, the U.S. News annual ranking of the nation's colleges and universities has become the "gold standard" of the ranking business" (Ehrenberg, 2001, p.146) (see Table 1).

This fascination with rankings is not something that is only seen in the United States, but is an increasing phenomenon around the globe. Higher education has transitioned from being a social expenditure to a prime component of the productive economy. Consequently, the way that higher education is both governed and administered has become a major policy issue. There is more emphasis on the notions of "value, return on investment, productivity, efficiency" (Hazelkorn, 2015). Because education and graduate school outcomes are strongly correlated with higher qualifications, career opportunities, and better quality of life, students have become savvier shoppers (Hazelkorn, 2009a). Moreover, because of the increasing costs that students 
face for higher education (which includes tuition, living expenses, relocation costs, etc.), students assess institutions as well as the programs nested within them not just as a cost, but also as an opportunity cost (Hazelkorn, 2015). It is not only about the monies students are going to spend on their education, but also about the possibilities they will have by choosing an institution over another. While Rutgers Business School is less expensive than Harvard, there are implied benefits to attending the latter that students consider.

\section{Table 1}

How the U.S. News Undergraduate Rankings Have Changed Over Time

1983 U.S. News publishes its first rankings of undergraduate programs.

1987 The rankings begin annual publication. They are expanded to the top- 25 research universities and liberal-arts colleges, and the magazine begins a separate ranking of institutions by region.

1991 The rankings for the first time include comparative data, such as graduation rates and acceptance rates.

1994 U.S. News begins publishing an annual guidebook with rankings of graduate programs.

1996 Numerical rankings are expanded to the top 50 universities and top 40 liberal-arts colleges.

1997 A consultant hired by the magazine says there is no scientific basis for the weights attached to the different categories, such as making "peer assessment" 25 percent of the overall score.

2000 The California Institute of Technology moves from ninth to first in the rankings of universities. After an outcry, the magazine changes its methodology. The following year, Cal-Tech slips to fourth place.

2001 Rankings of liberal-arts colleges are expanded to 50. 
2004 U.S. News drops "yield" (the percentage of admitted students who enroll) as a factor after critics say it was the reason many colleges were starting early-decision programs. Rankings are expanded to the top 125 universities and top 110 liberal-arts colleges.

2015. U.S. News ranks 202 National Universities and 181 Liberal arts colleges; includes 6-year graduation rate and freshman retention rate as part of the data. Other colleges are included and not ranked. There is a separate ranking for regional colleges.

(Farrell \& Van Der Werf, 2007; Grewal et al., 2012; USNEWS, 2015).

\section{History of the Business School Rankings}

The practice of ranking graduate programs dates back to 1925, when Professor Donald Hughes ranked graduate programs in the United States on the basis of peer reputation (Shin, Toutkoushian, \& Teichler, 2011). The practice of ranking business schools in particular can be traced back to 1977, when The Carter Report, the Ladd and Lipset Survey, and the now defunct MBA Magazine, were published (Schatz \& Crummer, 1993). The Carter report solely measured research output. The Ladd and Lipset survey asked faculty who were teaching at different business schools which schools they thought were best. MBA Magazine asked deans to vote to determine rank. As was expected, different criteria delivered different results. But in 1988, John Byrne at Business Week magazine designed a survey that was set to incorporate criteria such as salaries into what came to be determined as business school success. This was the first type of business school ranking to have wide circulation and that stopped using solely industry insiders. The ranking focused on student scores, which accounted for $45 \%$ of the score; recruiter scores, which accounted for another $45 \%$; and intellectual capital, accounting for the last $10 \%$ (Peters, 2007). Intellectual capital was described by Business Week as "the power and quality of ideas generated by Business school faculty" or in other words, research. 
By 1990, U.S. News came out with its ranking of MBA programs. This new ranking added components and built on the existing Business Week iteration, but it divided its scores in the following ways: $40 \%$ of the total score was allocated to measuring reputation, $35 \%$ was affected by placement success, and the last $25 \%$ corresponded to student selectivity. After almost a decade of the market being monopolized by these two rankings, the Financial Times, in 1997, released an international ranking, as a response to criticism that both existing rankings had gathered; mainly for being too U.S.-biased. The Financial Times looked to award $20 \%$ of its score for international diversity, $25 \%$ for research performance, $40 \%$ for salary progression, and the last $15 \%$ was based on student selectivity and quality (Peters, 2007).

\section{College Choice and the Rankings}

Students often use rankings when they apply and matriculate to a college or graduate school (Shin et al., 2011). They look to determine what school will be best for them, and which one will provide the biggest boost to their careers (Dearden et al., 2014). Consequently, universities are concerned with maintaining and improving their position in the rankings because this correlates with their ability to attract, enroll, and graduate high-performing students, as well as to attract and retain the most prominent faculty and generate high caliber alumni donations (Shin et al., 2011).

When looking at which institution to attend, most people are not only influenced by their perceptions and attitudes, but also by what other people think. For example, a parent may think that the local institution is an excellent undergraduate choice, but would still rather have his son attend a "big name" university, even if there is no actual difference in educational quality (Bowman \& Bastedo, 2009). Parents and students place a larger emphasis on attending top 
ranked institutions versus other institutions, because these higher ranked colleges and universities help them obtain the best jobs (or graduate schools) and to join the elite professional class of society (Espeland \& Sauder, 2007). In some cases, students value rankings, depending on whether the criteria for the rankings are important to them and whether those criteria are properly measured. However, this is not the norm. (Shin et al., 2011). In most cases, the rankings are based on a set criteria that may be what the publisher determines to be the best methodology, but may not be the most helpful or even appealing to students.

Rankings can have two different roles in a student's decision process. They can either inform a student about the qualities of an institution, or they can influence a student not to attend a certain institution. Dearden et al. (2014) used the neoclassical economics theory of decisionmaking to explain that students assign utilities to universities and then use those utilities to determine which universities to investigate, to apply to, to visit, and eventually to matriculate to. Still, to see rankings as either informative or persuasive comes from the point of view of economists. Advertising is either persuasive - in that it can alter a consumer's opinion and perceived ideas - or informative, in that it can provide new information to the consumers about attributes, points of sale, or that a college even exists (Bagwell, 2007).

Rankings can influence students in that they, together with their parents and families, may see the rankings as an expert opinion that provides them with a definition of institutional quality (McDonough et al., 1998). Students may think that the rankings, because they compile statistics --which are objective--and the opinions from pertinent individuals and stakeholders-which can be subjective--address all possible aspects needed to make a decision. Thus, this method of decision-making becomes the simplest and best possible chance at research. Bastedo and Bowman (2010), believe that a different subset of students and parents are also likely to 
internalize the rankings presented to them without even exploring what they mean and make these their opinion. This gives this subgroup some hierarchy of the institutions that are considered best. Yet, these newly internalized rankings may not necessarily align with the individual's own notion of quality or need. For example, what happens when a student is looking to stay within a certain geographic location (e.g. proximity to home) and the rankings do not provide institutions that fit this criteria, since they only provide national or regional (Northeast, Southwest) categories?

Bowman and Bastedo (2009) argued that rankings can influence the institutions to which a student applies on the basis of the admissions statistics. Students can determine the likelihood of being accepted to a particular school based on the SAT, ACT, GMAT, and GRE score that they earned, their class rank, undergraduate Grade Point Average (GPA). Therefore, knowing those statistics, students can determine whether they want to apply to (based on the probability of being accepted) a particular institution or not.

In the case of business schools, GMAC's Global MBA Survey (as cited in Tyson, 2001) showed, and this was confirmed in GMAC surveys throughout the following years, that $95 \%$ of the graduating MBAs said that school rankings had more influence on their decision-making process than any other source. Rankings "remain as the primary means by which observers evaluate business school reputation, and they continue to be used by organizational scholars" (Vidaver-Cohen, 2007 p.282).

\section{U.S. News and World Report}

There is extensive literature that argues that, especially during the past 15 years, studying and making sense of the U.S. News rankings has become somewhat of an industry (Bowman \& 
Bastedo, 2009; Griffith \& Rask, 2007; Martins, 2005; Meredith, 2004; Monks \& Ehrenberg, 1999; Volkwein \& Sweitzer, 2006). To put things in perspective, the U.S. News website, on average, receives approximately half a million views per month. However, in 2007, within 3 days of publishing the rankings, the website had received roughly 10 million views (Friedman, 2007). This shows the degree to which some students rely on the release of the yearly rankings. The literature shows that rankings have become important because consumers, often with limited attention spans or knowledge, value the aggregation of information because it simplifies a decision process and provides some added comfort when they have to make big decisions (Meredith, 2004).

As previously stated, the literature regarding the U.S. News rankings has been widely researched. Monks and Ehrenberg (1999), two well-regarded authors in this field, demonstrated a strong correlation between rankings and application decisions. A major concern with Monks and Ehrenberg's conclusion stems from the range of scores they analyzed. Unfortunately, due to the data they had available at the time they included only 16 of the top-25 national universities and one university ranked between 26 and 50 and 13 of the top-25 national liberal arts colleges in the U.S. News 1998 rankings (Monks \& Ehrenberg, 1999). However, they still showed that a change of one rank in the U.S. News ranking would correlate with a change of $0.4 \%$ in the acceptance rate, a change of $0.2 \%$ in the yield, and a variance of 3 points in the mean SAT score of the applicant class. Moreover, they saw that an improvement of one rank would allow a school to increase net tuition by $0.3 \%$. Conversely, moving down a place in the U.S. News rankings from 4th to 5th would signify an increase in the university's admission rate, a decrease in matriculation rates, and a decrease in the quality of the entering class, as shown by standardized scores. This correlation between rankings and applications, Luca and Smith (2013) observed, 
was stronger for schools ranked 1-25 than for schools ranked 26-50. Luca and Smith (2013) used all available data (in some years top-25, and in some years top 50, from 1990-2000) in order to arrive to their conclusion. However, the main concern with their data is that, at this point, it is between 15 and 25 years old.

Griffith and Rask (2007) used student data to show the effect of an increase in the rankings in admissions statistics. They looked at the probability that students would actually attend a specific institution in relation to how it performed in the U.S. News rankings, as well as other factors. They found that once other variables were controlled, students were more likely to attend schools with a higher ranking, regardless of whether these were national universities or national liberal arts colleges. This became more pronounced among the top-ranked universities. The main limitation of this study was that the data used by Griffith and Rask was heavily weighted towards national liberal arts colleges, which represented $62 \%$ of the schools, whereas only $32 \%$ were national universities.

Bowman and Bastedo $(2009,2011)$ showed the effect of several outcome variables that were correlated with being ranked in the top 50. They found that the effect on admissions of mobility in rank was most pronounced when a university moved into the top-25 of the rankings. Luca and Smith (2013) also found that improvements in the rankings caused increases in student applications. What was interesting about this was that despite the reliance on rankings by students, some institutions chose to refrain from reporting information to U.S. News because they feared that a negative ranking would impact potential students and thus decrease the number or quality of their incoming class (Strauss, 2007). Still, it is understandable that if an institution cannot make it to the ranking it desires; perhaps it behooves the institution not to be ranked at all. A low ranking (such as 120 in a top 125) can still be a good recruiting tool (Thurman \& 
Efimova, 2014). Yet, if an institution knows that this is unattainable (and this can be known based on previous years' benchmarks and criteria), limiting exposure and damage by stating that they refuse to participate may not necessarily be a bad idea. Some institutions that have chosen not to participate in the rankings have included: Southwestern University, Drew University, Kutztown University, Saint Mary's College of California, Muhlenberg College, Wesleyan College, amongst others (The Education Conservancy, 2007).

\section{U.S. News and the Business School Rankings}

Despite some exceptions, most researchers, when dealing with business school rankings, have accepted popular media rankings of business programs as being "sufficiently reliable" and "valid enough," so as to start building theories and trying to draw conclusions in regard to business schools reputations (Vidaver-Cohen, 2007). Media rankings have become increasingly important to business schools (Trieschmann, Dennis, Northcraft, \& Nieme, 2000). Yet, there is a strong aura of caution when making inferences, since as Vidaver-Cohen (2007) have noted, rankings are "sufficient" and "valid enough" but not considered flawless by any means; in fact, "the validity of current ranking systems and league tables as credible measures of reputation has been soundly criticized by educators, scholars, accreditation agencies and business school consumers alike" (Vidaver-Cohen, 2007 p. 278).

The recent "boom" of business schools can be seen from data regarding growth. In 1974 there were only 370 graduate business schools in the United States; however, by the year 2000, that number had risen to almost 800 programs that produced 40,000 to 50,000 students per year with a degree (Green \& Reingold, 1999). As of 2012, there were 488 AACSB (Association to Advance Collegiate Schools of Business), 322 ACBSP (Accreditation Council for Business 
Schools and Programs) and 133 IACBE (International Assembly for Collegiate Business

Education) accredited business schools in the US, for a total of 943 accredited business schools (Brink \& Smith, 2012). AACSB is the "gold standard" when it comes to business school accreditation: It is the best regarded in the field, and the accrediting body for most top business schools. The AACSB website (n.d.) states: “AACSB Accreditation is known, worldwide, as the longest standing, most recognized form of specialized/professional accreditation an institution and its business programs can earn".

If one looks at more data regarding the impact of the rankings, it can be seen that the Wharton School of Business at the University of Pennsylvania was ranked number 1 in Business Week's biannual ranking four consecutive times (between 1994 and 2000). In those years, their applicant pool went from 4,300 in 1993, to 8,400 in 1999 (Wuorio, 2001). After a 2001 Wall Street Journal article which ranked the Tuck School of Business at Dartmouth first, inquiries increased from about 7,500 in September 2000 to more than 12,000 a year later (Wuorio, 2001). This further illustrates the power rankings can have on students.

Higher education administrators, educators, and even accreditors have been outspoken about concern that the overreliance on rankings to measure the quality of a business school can actually drive administrators to focus on improving ranking positions rather than the actual quality of their programs or meeting the needs of their students and stakeholders (Policano, 2007). Scholars have long stated that rankings, as valid measures of reputations, can be problematic, often characterizing them as noisy signals which hinder rather than aid the assessment of organizational quality (Dichev, 1999).

Pat Harker, Dean of the Wharton School of Business (as cited in Vidaver-Cohen, 2007) stated, 
There is a very strong consensus...that the ranking methodologies are severely flawed. Some people who agree with that also ask, "if the rankings help us, who cares if they are flawed or give only a limited view of the school?' But we can't have it both ways. We either endorse a defective, inconsistent practice, or we speak out, offer better alternatives for information, and work with the media to enable them to report with more useful, objective data. (p. 279)

As can be seen from this quote, administrators are in a tough position. They must balance not wanting to overemphasize the weight of their rankings with ensuring that they do everything possible not to slip in the rankings and to increase their position in the rankings, since there is substantial literature that has shown that there is a correlation between the quantity and quality of an applicant pool and school variance in the rankings, combined with the notion that the quality of their school is being represented by a single number published by an outside for-profit entity (Griffith \& Rask, 2007). Moreover, Griffith and Rask (2007) have found that students' choices are very responsive to changes in rank. They found that the higher the position an institution occupies in the rankings, the better the opinion students have of it, therefore making it logical for administrators (especially at highly-ranked institutions) to pay close attention to the U.S. News rank. Griffith and Rask (2007) used data from Colgate University’s admitted student questionnaire for undergraduates and found that full-paying students' enrollment decisions were particularly sensitive to the U.S. News rankings and were especially sensitive to the top of the ranking distribution.

To further the points articulated earlier regarding U.S. News, Bednowitz (2000) furthered the study of his mentor, Ronald Ehrenberg when he conducted the same study using business schools instead of undergraduate institutions. He found that the findings were consistent for both business schools and undergraduate rankings in that a fall in the rankings affected the admissions 
statistics of a business school. However, he added that, in business schools, administrators were often forced to either cut tuition or increase scholarship monies in order to attract more students from its declining applicant pool, when the institution fell in the U.S. News rankings. Yet, a school soaring in the rankings can be selective as to which students to select, and can even have the flexibility to raise tuition. A one position change in ranking is associated with a statistically significant change in tuition of \$218.61; however, it should be noted that Bednowitz's data only uses the top-25 (ranked institutions).

By using Monks and Ehrenberg's data from 1999, Bednowitz (2000) was able to show that a one position decrease in the business school rankings (from 4th to 5th) results in a statistically significant increase in the admission rate of a program (more than half a percentage point), this is usually done to meet an enrollment target for the incoming class. "For example: If Duke's business school fell one place in the U.S. News rankings, its yield rate would fall from $57 \%$ down to $56.27 \%$. If the school wished to maintain its class size of 660 people, it would have to admit 15 more people, a change of $1.3 \%$ (from 1,157 to 1,172)" (Bednowitz, 2000, p.14) According to Bednowitz's (2000), employers do not respond to short-term changes in ranks; however, should there be a prolonged change in the ranking of a school, then this would lead employers to modify their behavior. For example, if a business school was to increase (long term) its position in the U.S. News ranking, then this would lead to more students receiving job offers, attaining higher salaries for said offers, and thus, a higher value for the MBA they received (if measured by the change in salary). Conversely, a program that saw long-term decline in the rankings would see fewer students obtain offers, options, and thus, a lower value for the program (Bednowitz, 2000). The reason for this is that employers have often had longstanding relationships with the programs out of which they recruit, and in many events there are alumni 
from these programs working at these firms. Therefore, to simply dismiss a program based on a 1-year fall in the ranking would not be feasible (Bednowitz, 2000).

\section{Business Schools and Reputation}

Vidaver-Cohen (2007) sees the reputation of a business school as the level of trust, admiration, respect, and good feeling that observers experience for the school, as well as the perception of the overall esteem of the school. Argenti (2000) defined the reputation of a business school as the aggregate of the perceptions of all stakeholders; this includes but is not limited to students, parents, recruiters, alumni, faculty, administrators, and so forth. Also, Argenti stated that the prestige of any given business school is strongly correlated to the reputation of its parent university. Nevertheless, different studies also showed the chance that the reputation of a parent school is often caused, in part, by the professional schools (business, law, and medical) that they have (Devinney, Dowling, Perm-Ajchariyawong, \& Dowling, 2006).

Sweitzer and Volkwein (2009) have argued that, at the undergraduate and graduate levels, size and admissions statistics (selectivity) are the main drivers of institutional reputation. However, at the business school level size, student quality, and rankings have become the main keys behind institutional reputation (Rindova et al., 2005; Safon, 2007, 2009; Sweitzer \& Volkwein, 2009).

Rindova et al. (2005) put forth a model for organizational reputation that they applied to business schools in the United States. They found that the reputation of a business school had two main components: (a) perceived quality - which is composed by the quality of inputs (incoming students are the major input to the category), and the quality of productive assets (faculty); and (b) prominence - by prominence they mean the history that exists pertaining to the 
school, and what current image it has as it pertains to rankings, research performance and employees with terminal degrees from prestigious institutions. The data from their study showed that the score in the Graduate Management Admission Test (GMAT) and the position in the rankings was crucial to forming perceptions of quality and prominence amongst recruiters, employers, and so forth.

Safon's (2012) position regarding business schools and reputation goes against the grain on this topic. Safon (2012) questioned the actions taken by business school administrators who wanted to improve the prestige and reputation of their institution in the short-term by manipulating the rankings. He argued that school reputation should be a result of developing a concise and coherent mission and vision over time, rather than taking the numeric approach at face value. To further this point, Lederman (2009) explained how, when President James Barker took over as President at Clemson and promised to move the institution into the top 20, he vowed to affect every possible indicator to the greatest extent possible. Clemson was seen as willing to alter its profile in order to improve its U.S. News standing. The easiest move involved class size: Increasing the amount of classes with fewer than 20 students (moving caps down from 20-25 to 18-19) and then compensating by letting 55 student classes go to 70 .

According to Safon (2012), the reputation of a business school can be explained by its past reputation, which explains more than $90 \%$ of its variance. This is consistent with previous research on universities and departmental reputations by Keith (2001), even though Keith (2001) stated that it usually takes 30 years for there to be a relevant modification in the reputation of a university. Safon (2012) argued that most of the literature regarding business school reputation has shown the minimal impact that reputation signals have on business school reputation in the short term. Many other researchers disagreed with him on this topic (Gioia \& Corley, 2002; 
Rindova et al., 2005; Safon, 2007, 2009; Vidaver-Cohen, 2007). They argued that media rankings have been one of the most important reputation signals reported in the literature, and that they are impactful when it comes to business school reputation. Still, Safon's (2012) research found that rankings ceased to be important when past reputation was used as a predictor. Nevertheless, he noted that there are short-term repercussions to the rankings which cannot be avoided. Fee, Hadlock, \& Pierce (2005) outlined that a bad performance in the rankings can be associated with an increase in probability in the departure of the dean of the business school. A drop of one position had a statistically significant probability, of under $3 \%$, of a dean leaving. However, the number increased to $10 \%$ when there was a drop out of the top 10 or the top 25 . Safon, supported by the research of Keith (2001) and Morgeson and Nahrgang (2008), concluded that reputation is a stable concept that, over time, balances itself out without the need for corrective actions alas an "invisible hand". Yet, another big issue acknowledged by Safon was that regarding reputation, subjective factors are most likely going to influence the prestige factor based on past accomplishments by an MBA program or parent institution, which may not be reflected at all in the current situation of the ranked program. Still, reputations, while they try to reflect earned achievements, also seem impervious to change from new challengers (Jeon, Miller, \& Ray, 2003).

\section{The U.S. News Methodology}

As Hazelkorn (2015) showed, one of the main areas of the literature, as it pertains to rankings, has to do with the methodological concerns, which deal with all the flaws and issues found in the rankings themselves. Therefore, for this section, I will address undergraduate and business school arguments alike. 
Rankings determine the level that each individual (business) school merits for any given criteria assessed, and then all of these are 1 combined into an overall score using an aggregation function (often a weighted sum of the levels) that is determined by the publishing company. Consequently, universities are ranked based on their overall scores. Very specific information is aggregated into broad categories for both the undergraduate and business school methodology (see Tables $2 \& 3$ ). These broad variables are ordinal; therefore, being ranked as number 1 is the best possible scenario for any school. Reputation is assessed by asking university presidents, provosts, and deans of Admissions to rank the reputations of other schools (in the case of business schools, recruiters, and employers are added). Selectivity is a combination of factors that includes standardized test scores (SAT or ACT, GMAT), the proportion of enrolled freshmen who were in the top $10 \%$ of their high-school class (for undergraduate rankings), or the undergraduate grade point average (for the business schools) and the yield. Faculty-resource has to do with the faculty-student ratio in the classroom, the percentage of faculty with $\mathrm{PhDs}$, the amount of faculty who are full-time, and the average class size. Retention and graduation deal with the number of students who return year over base and who graduate from the institution. Financial resources encompass the amount of expenditures per student, and finally alumni-giving deals with the percentage of alumni who donate back to the institution (Luca \& Smith, 2013).

Dearden et al. (2014) pointed out that most of the attributes used by ranking systems are multidimensional and can be measured in many different ways. In order to measure the quality of an entering class, a publication can use the 25 th or the 75 th percentile of their SAT scores or rank index and SAT scores (when dealing with undergraduate admissions), but this does not mean that all publications use the same attributes or measures of the same. 
Table 2

Ranking Indicators of U.S. News and World Report Undergraduate Rankings (for National Universities and Liberal Arts Colleges) - 2015

\begin{tabular}{|c|c|c|}
\hline Indicator & Percentage & Description \\
\hline $\begin{array}{l}\text { Undergraduate } \\
\text { academic reputation }\end{array}$ & $22.5 \%$ & $\begin{array}{l}\text { Peer assessment survey - Relies on the opinion of } \\
\text { president, provost, dean (from peer institutions) Based } \\
\text { on a } 5 \text { point scale rating academic programs ( } 1 \text { - } \\
\text { marginal to } 5 \text { - distinguished). }\end{array}$ \\
\hline Retention & $22.5 \%$ & $\begin{array}{l}\text { Based on the percentage of freshmen who return to } \\
\text { campus for sophomore year - } 20 \% \text { of score and } \\
\text { eventually graduate }-80 \% \text { of score. }\end{array}$ \\
\hline Faculty Resources & $20 \%$ & $\begin{array}{l}\text { Calculated components include: } \\
\text { (1) Class size (fewer than } 20 \text { students - } 30 \% \text { of score } \\
\text { and those with } 50 \text { or more students - } 10 \% \text { of score) } \\
\text { (2) Average faculty salary - } 35 \% \text { of score } \\
\text { (3) Proportion of professors with highest degree in } \\
\text { fields } 15 \% \text { of score } \\
\text { (4) Student-faculty ratio } 5 \% \\
\text { (5) Faculty who are full-time } 5 \%\end{array}$ \\
\hline Student Selectivity & $12.5 \%$ & $\begin{array}{l}\text { Calculated components include: } \\
\text { (1) SAT / ACT score }-65 \% \text { of score } \\
\text { (2) Enrolled freshmen who graduated in the top } 10 \% \\
\text { of their high school }-25 \% \text { of score } \\
\text { (3) Acceptance rate or ratio of students admitted to } \\
\text { applicants } 10 \% \text { of score. }\end{array}$ \\
\hline Financial Resources & $10 \%$ & $\begin{array}{l}\text { Based on per-student spending on programs and } \\
\text { services; calculated by using the average spending per } \\
\text { student on instruction, research, student services and } \\
\text { related educational expenditures. Spending on sports, } \\
\text { dorms, and hospitals are not included. }\end{array}$ \\
\hline $\begin{array}{l}\text { Graduation Rate } \\
\text { Performance }\end{array}$ & $7.5 \%$ & $\begin{array}{l}\text { Based on the effect of college programs and policies } \\
\text { on the graduate rate of students after controlling for } \\
\text { spending and student characteristics. A predicted } \\
\text { calculation is derived and then compared to the actual } \\
\text { graduation rate to determine if the college is } \\
\text { enhancing achievement }\end{array}$ \\
\hline Alumni Giving & $5 \%$ & $\begin{array}{l}\text { Based on the average percentage of alumni with } \\
\text { bachelor's degrees who donate to their school. }\end{array}$ \\
\hline
\end{tabular}


Table 3

Ranking Indicators of U.S. News and World Report for MBA Programs (2015)

\begin{tabular}{|c|c|c|}
\hline Indicator & Percentage & Description \\
\hline Quality Assessment & $40 \%$ & $\begin{array}{l}\text { Peer assessment score (25\%): } \\
\text { In fall 2013, business school deans and directors of } \\
\text { accredited master's programs in business were } \\
\text { asked to rate programs on a scale of } 1 \text { (marginal) to } \\
5 \text { (outstanding). } \\
\text { Recruiter assessment score (15\%): } \\
\text { In fall 2013, corporate recruiters and company } \\
\text { contacts, whose names were supplied to U.S. News } \\
\text { by MBA programs previously ranked by U.S. } \\
\text { News, were asked to rate all full-time programs on } \\
\text { a scale from "marginal" (1) to "outstanding" (5). }\end{array}$ \\
\hline Placement Success & $35 \%$ & $\begin{array}{l}\text { Mean starting salary and bonus (14\%): } \\
\text { Average starting salary and bonus of } 2013 \\
\text { graduates of a full-time master's program in } \\
\text { business. } \\
\text { Employment rates for full-time master's program in } \\
\text { business graduates: This is the employment rate for } \\
2013 \text { graduates of a full-time master's program in } \\
\text { business. } \\
\text { Employment rates at graduation }(7 \%) \text { and three } \\
\text { months after graduation }(14 \%) \text { are used in the } \\
\text { model. }\end{array}$ \\
\hline Student Selectivity & $25 \%$ & $\begin{array}{l}\text { Mean GMAT and GRE scores ( } 16.25 \%) \text { : } \\
\text { Average Graduate Management Admission Test } \\
\text { (GMAT) score and average GRE scores of full- } \\
\text { time MBA students entering in fall } 2013 \text {. } \\
\text { Mean undergraduate GPA }(7.5 \%) \text { : } \\
\text { Average undergraduate grade-point average of } \\
\text { those students entering the full-time program in fall } \\
2013 \text {. } \\
\text { Acceptance rate (1.25\%): } \\
\text { Percentage of applicants to the full-time program in } \\
\text { fall } 2013 \text { who were accepted. }\end{array}$ \\
\hline
\end{tabular}




\section{Critiques of the Methodologies}

U.S. News has warned its readers that it regularly "may change" its methodology: "Since we may change our methodology from year to year, we do not invite readers to track colleges' annual moves in the rankings" (Morse \& Flanigan, 2000, p.104). While this language is no longer on their website, there is a question on the FAQ for the website that asks, "Why does the methodology change most years?" This, is followed by: "What changes if any, were made this year to the methodology and the rankings?"

The success and influence of the U.S. News rankings have made institutions take action in order to compensate or account for these changes in the methodology. Actions taken to manipulate the rankings have sparked a desire in academia to develop a new ranking methodology that avoids some of the manipulation that has transpired recently (Dearden et al., 2014). In a survey that Inside Higher Ed administered to admissions directors in 2012, it was found that $91 \%$ believed that some institutions reported false scores or other data (Jaschik, 2013).

Farrell and Van Der Werf (2007) stated that there are many well-documented examples of institutions that asked their alumni for nominal contributions in order to increase their percentage of giving; encouraged students to apply who they knew had no opportunity of getting in; artificially drove up the number of applicants by counting incomplete applications as complete; or creatively reinterpreted how data could be reported to U.S. News to minimize any impact. "Albion College (for example) took one-time gifts from graduating seniors and spread them over five years in order to boost its alumni-giving rate" (p. 3).

Other practices have included: failure to report standardized test scores from underperforming foreign students, athletes, or any other special admission categories; overinflating per capita expenditures by misclassifying expenses for athletics, faculty research, 
and other enterprises; and boosting the yield rate by rejecting or wait-listing the high achieving students in the applicant pool (who are unlikely to attend the institution, even if admitted) (Diver, 2005). Because the administrations of institutions realize the importance of rankings, self-report data has often lead them to file fraudulent reports. Some recent offenders include: Baylor University, Bucknell, Emory, Iona College, and George Washington University, as well as Claremont McKenna College (Hechinger, 2013; Hoover, 2012).

In other cases, many presidents, provosts or deans, have stated that they respond to every institution in a similar fashion, or in one which highlights its own institution; "the University of Florida's and Clemson University's presidents, rated their own institutions well above many of their competitors... The provost at the University of Wisconsin at Madison deemed 260 of its 262 peer institutions to be of adequate quality (Lee, 2009). The only other two ratings he provided (which are the highest possible, that is distinguished) went to his own institution and to The New School. It should be noted that adequate, is considered the second lowest possible rating; and the group of 260 institutions rated, included all Ivy-League universities, MIT, Stanford, and Cal Tech amongst others.

However, there are also cases in which presidents, provosts and deans have decided to stop submitting data to U.S. News almost as a measure resembling civil disobedience, but in those cases, the results have often been dire. U.S. News, despite being told to omit these institutions from the rankings, has tried to find the required information from other sources, and in cases when it could not be gathered it assigned the institution the lowest possible score in the category; thus dropping its ranking (Diver, 2005). Some presidents, such as Daniel M. Fogel, president of the University of Vermont, are very indifferent towards the survey, and although they fill the survey, they do it without any purpose, and do it in a hurry. When asked why this 
was the case, his response was the following: "Nobody's paying us to help U.S. News produce a commodity.... When I'm being paid hundreds of dollars a day, why would I spend time reading up on South Dakota State (University) so I can give U.S. News a better answer?” (Lee, 2009). It should be noted that because the rankings rely mainly on unaudited, self-reported data, it is very difficult to ensure that the data is accurate. Hence, the reliability of the rankings cannot be verified.

Jaschik (2013) has investigated U.S. News and their response to the issues surrounding false or inaccurate information. U.S. News has been considering a plan of action through which institutions would be required to have a senior official sign a statement that verifies the accuracy of the information that is provided. Brian Kelly, editor and chief of content at U.S. News has compared this idea to the Sarbanes-Oxley act. Kelly's opinion regarding this issue is that there is no need for U.S. News to come up with an exact method for data verification since,

"We're not the accreditor. We're not the federal government. We don't want to be a regulator. We're journalists; the burden is on these schools to be accurate. It's their reputations. It's their customers." (as cited in Jaschik, 2013)

U.S. News as a private, for-profit company, ought to think strategically about how it can maximize its profits. Unless there is change in the year-to-year rankings, how can they justify a new edition and report? Therefore, to entice students to acquire the newest issue, they need to constantly claim that they are improving the methodologies in order to come up with the most recent rankings (Dearden et al., 2014). Criticizing the statistical validity of the rankings, the way in which the weights have been assigned, the methodologies utilized, and the factors used in any of these ranking systems is easy (Peters, 2007). Schatz \& Crummer (1993) stated that the 
methodology of the rankings "could not get a passing grade in any of the schools that are surveyed by the rankings" (p.17).

Further, in the case of U.S. News, it is impossible to predict true rank because without the salaries of the faculty (which affect one of the variables), the validity of the ranking cannot be determined (Luca \& Smith, 2013). They further state that although U.S. News publishes many variables, they still do not publish all of the ones that go into each category; specifically, in the case of faculty resources. Moreover, they claim that the weights in this and other subcategories are excluded. For example, selectivity rank is understood to be acceptance and high-school achievement, but U.S. News only provides a weight for the entire category. Are the subcategories weighted at all? If they are, in which way (Luca \& Smith, 2013)? Moreover, although U.S. News attempts to have an objective system towards its ranking system, the fact that the data it uses to score the institutions is reported by the institutions themselves is problematic, since different institutions may report their data differently. If one wanted to think deviously one could argue that this may lead or allow some institutions to misreport data (Ehrenberg, 1999). "High stakes rankings create more incentive for schools to publish inaccurate or misleading data" (Alter \& Rebach, 2014, p.7).

In the specific case of business schools, Devinney et al. (2006) state that it is best when they state that the issue with the rankings starts when the rankings are seen as a valid proxy for a business school's reputation. The fact that there are several different rankings, all of which do not arrive at the same score, even within the same publication, year after year, the criteria (and positions) change, constitutes a problem. Yet, what is more problematic is that no rationale is given for all of these changes in the weighting structure. To support this argument, Policano (2007) showed that if the weights for the U.S. News rankings were changed so that each criterion 
had equal weight, then schools would change positions across the board. For example, while for some schools their ranking would not have changed (the number 1 ranked school in U.S. News would remain ranked number 1 with the new criteria); the school ranked number 6 by U.S. News, would jump to number 3; the school ranked 20, would now be number 30; and the school ranked 31, would become 23 (Policano, 2007).

Another issue, perhaps more revealing, is that the differences in raw scores between the highest and lowest ranked business schools are virtually negligible; yet, users of the ranks believe there is a much larger quality difference between these institutions, solely based on their ranking positions. In fact, the statistical difference between a school ranked numbers 1 and 2 may be almost imperceptible; however, the impact of the ranking is not. Moreover, year after year these institutions (ranked 1 and 2) may alternate the top position. Yet, a casual observer may believe that the top ranked institution has a lot more quality just on the basis of the ranking (Vidaver-Cohen, 2007).

On the other hand, Ehrenberg (1999) noted that there was a tendency amongst some higher education administrators to blame U.S. News and its rankings for many of the problems that their institutions suffer, but, in his opinion, rankings are a manifestation of the competitive environment that surrounds higher education. Despite him having showed the reasons why institutions should engage in the "rankings game"; he goes on to state that the rankings do not penalize institutions for cooperating with one another to improve the services they are providing for their students or even to increase the efficiency of their resources. 


\section{Institutions and the Rankings}

The last area that can be discerned from the rankings and their impact pertains to reputation and behavior; in other words, how institutions adapt to the rankings. Berger's (2000) organizational behavior theory is important to understanding this adaptation. Berger argued that the behavior of a higher education institution is a reflection of those who lead, operate, or provide services within the institution (i.e. administrators, faculty and staff). Berger wrote that, "it is important to remember that organizations do not behave; however, the people in those organizations do behave, while acting in the service of organizational interests" (p.4). Berger developed a structure with five distinct areas: bureaucratic, collegial, political, symbolic and systematic. By developing models for the five areas of organizational behavior that Berger developed, researchers can hypothesize why institutions can perform better than other colleges and universities.

Institution administrators have complained about the influence of college rankings. "These rankings have become increasingly legitimate and nearly impossible to ignore, particularly for elite universities and liberal arts colleges” (Bastedo \& Bowman, 2010, p.164). The rankings are undoubtedly a force in organizational policy and decision making, as well as, identity (Elsbach \& Kramer 1996; Espeland \& Sauder 2007). In fact, Mark Gearan, President of Hobart and William Smith Colleges, during an interview in October 2000, was quoted as saying that when he became president he felt the U.S. News ranking was critical to the institution, and thus, he had to devote a good amount of time during his first months in office to the rankings (Ehrenberg, 2003). Still, some presidents and provosts refuse to fill out the surveys sent out by U.S. News because they do not want to be ranked by an outside entity. In 2010, 66 university 
presidents refused to complete the survey and sent a letter to U.S News letting them know of the decisions (Ashenfelter, 2010).

Martins (1998) examined the responses from 59 students at ranked schools as to whether rankings were good or bad. To no surprise, schools that were ranked highly responded that the ranks were good, and schools that were not ranked as high questioned the validity of the rankings. Yet, it was the well-ranked schools that took measures to adjust the criticisms generated from the rankings in order to solidify their position in them. The administrators at the lower performing schools, believing there was no chance of penetrating the rankings, did not spend as many resources trying to address the issues. "The snowball effect of the rankings promotes a 'rich get richer and poor get poorer' cycle and creates a 'Catch-22' trap from which it is difficult to extricate oneself, win or lose" (Pettigrew, Cornuel, \& Hommel, 2014, p.252).

Universities value rankings, but rankings are a zero-sum game: for a university to move a spot, it needs to displace another. Therefore, universities need to act strategically in order to move up or to not move down in the rankings. That said, many questionable behaviors are aligned with those objectives which include: (a) the rejection of overqualified candidates who would hurt the rank of an institution if they were admitted but did not attend the institution (reducing the yield), and (b) the encouragement of less than qualified candidates to apply, only so they can be rejected, so as to decrease the acceptance rate or increase the exclusivity rate (Golden, 2001a,b).

Thompson (2000) argued that the rankings are basically a test for administrators to teach to, and that society puts too much emphasis on the results. His main argument is that this test does not measure anything since people do not actually recognize it, and there are better methods to address what they try to do without omitting all of the factors the rankings do. 


\section{Theories and Alternatives}

Pfeffer and Salancik (2003) have put forth an interesting theory in that of resource dependence. Resource dependence theory holds that the attention an organization pays to its stakeholders should also reflect the reliance of said organization on the stakeholders for resources. This infers that private institutions (which do not receive state aid) are more dependent on its stakeholders to stay in business; hence, they are more likely to, or should, devote more time and effort to managing issues that impact any publicity that deals with their constituency (e.g. MBA rankings). Conversely, since some public institutions have at least some funding which is guaranteed by their state, they are able to devote less attention to this, thereby satisfying their stakeholders via the rankings, and instead emphasize their efforts in research or other knowledge expanding endeavors (Trieschmann, et al., 2000). Still, trying to research institution-wide performance can be problematic due to the many constituencies that are served (Johnson, 2006; Pfeffer \& Salancik, 2003).

Luca and Smith $(2013,2015)$ have developed the concepts of salience and countersignaling in regards to both university and business school rankings. Salience is defined as “the simplicity of determining a given college's ranking. If U.S. News explicitly published a ranking, it would be more salient than if U.S. News published only the underlying quality and a methodology for computing the ranking. Publishing rankings makes them easier for applicants to compute, and also makes the information more readily visible" (Luca \& Smith, 2013, p.1). This is done because there is evidence that shows that consumers respond differently to information when it is salient than when it is shrouded (Luca \& Smith, 2013; Pope, 2009).

To understand the concept of countersignaling, it is imperative to first define what signaling is. Signaling is defined by Feltovich, Harbaugh, \& To (2002) as the costly "signal" that 
high-performing types or actors send in order to differentiate themselves from lower performing individuals. An example of signaling is a company that holds an IPO (initial public offering) of stock. If the owner retains a large share of stocks, this signals he has faith in the future of the company. Companies that have uncertainty about the future or are under duress would be unwilling to replicate the signal. In the case of the rankings, signaling would have to do with different institutions listing as many awards and recognitions (including positions in their rankings) to signal their cache to potential customers in order to lure their business.

Thus the theory of countersignaling, in this context, makes reference to the considered top universities not disclosing their rankings or other accolades. Because they know that other information about them is favorable enough and that students are well aware of this reputation; they find no need to disclose their rankings (Luca \& Smith, 2015). Countersignaling can be further explained as "showing off, by not showing off"; a good analogy to this can be how the nouveau rich are known to show off their money, by flashing it and buying expensive ostentatious materials, whereas the old rich may not find the need to signal their monies (i.e. display it) and instead choose to countersignal by not displaying their wealth as much.

This said, Feltovich et al. (2002) found that mid-ranked business schools were more likely to post their rankings so as to separate themselves from lower ranked ones. They explained that schools that perform poorly in the U.S. News rankings or were unranked altogether were more likely to disclose their Princeton Review Certification or their Association to Advance Collegiate Schools of Business (AACSB) accreditation. To further this point, Luca and Smith (2013) explained that none out of the top 50 institutions in the U.S. News ranking published any of these two, but $30 \%$ of the unranked schools mentioned their Princeton Review status. Furthermore, when a school chose to display a ranking, the vast majority of them coarsened the 
information to make it seem more favorable with phrases like, "top ranked program" or "top-50 institution," instead of reporting, "ranked 50" (Luca \& Smith, 2015). While this information is verifiable, the selective disclosure and manipulation of information dilutes the idea of voluntary disclosure.

When the rankings are examined one can see that the criteria for the rankings are defined independently of the business schools themselves and that they change over time. Therefore, even if administrators want to increase their position relative to the rankings, can they? Just looking at U.S. News and Business Week (see Table 5 for current ranking \& Table 6 for Business Week methodology), more than 90 different attributes are measured (Peters, 2007). Thus, despite their limitations, business schools understand the power that the rankings exert (Peters, 2007). Corley and Gioa (2000) wrote that institutions are in a catch-22 with regard to the rankings. They did so based on Giddens' (1976) theory of structuration, which states that there is a recurrent relationship between structure and action, which over time tends to affect structure. According to this theory there is a symbiotic relationship between rankings and institutions, so rankings are bound to affect institutional behavior. Corley and Gioa (2000) explained that the "rankings game" has five maxims: (a) you have to play, or be at a significant disadvantage against others, (b) once you start playing you have to keep playing and cannot quit; otherwise the consequences can be dire, (c) there is no point complaining or undermining the rankings because they are here to stay, and you have likely opted into the rankings, (d) criteria will continue to change over time and there is nothing you can do about it, except continue to adapt, and (e) there is no way to actually win this game.

Another way to look at the quality of business schools and the rankings is to take a look at a value-added approach. Tracy and Waldfogel (1997) use a market-based theory to make sense 
of business school rankings. By using regression analysis, they determined what the value added by an MBA program actually was, and then they assessed the actual value and rank of an MBA program. Tracy and Waldfogel make a valid theoretical distinction between the quality of a given MBA program and the quality of the students that attend it. Therefore, before performing a regression with the average starting salary (after adjusting for cost-of-living), they looked at a myriad of student attributes. This is information that becomes very valuable to potential MBA students, but not as valuable to employers or administrators, since a program they rank high may start with lower quality students, and that may not be what employers want. This type of approach to the business school rankings would be surprising if, for example, the top 10 list included Harvard and the University of Chicago were joined by the University of New Mexico and Oklahoma State.

Jeon, Miller, and Ray (2003) used net salary gain in order to determine the quality of an MBA program. Pre- and post-MBA differences in salaries (adjusted for tuition and fees) were the main part of a set of outputs that included the number of offers received as well. The inputs in their model were student characteristics. To illustrate this, "Harvard's MBA graduates had an average starting salary of $\$ 90,675$ and a total compensation package of $\$ 163,792$ for the class of 1998. The graduates of Marriott School of Business at Brigham Young University (BYU) had an average base salary and total compensation package of $\$ 66,789$ and $\$ 99,180$, respectively” (Jeon, Miller, \& Ray, 2003, p.3). Jeon, Miller, and Ray further illustrated that often the pre-MBA salaries of Harvard students are much higher than those of students at BYU $(\$ 68,000$ versus $\$ 27,684)$. Consequently, when they accounted for the differences in tuition, expenses, and other costs, the annuitized value of the gain in earnings for BYU graduates exceeded that for Harvard graduates (Jeon, Miller, \& Ray, 2003). 
The concern Jeon, Miller, and Ray had with the U.S. News (and Business Week alike) rankings was that they mixed the responses of students, employers, recruiters, and other stakeholders together in order to come up with an overall evaluation of the business school. At issue here is that all of these stakeholders have different interests, which, in the opinion of Jeon, Miller, and Ray, should be ranked independently. Subsequently, their rankings provided different rankings for three different groups (students, employers, and program administrators).

Jeon, Miller, and Ray (2003) argued that the U.S. News ranking system relied on a somewhat biased survey response system, since it depended on the participants (and stakeholders) from business schools; and thus, participants might have been inclined to use subjective factors (e.g. "I love the school I attend," or "I hate Harvard because I am a Yale alumnus") as much as objective ones. It is their argument that since survey respondents often may not have all of the accurate information regarding programs, the subjective factors will tend to influence the reputation of the programs that receive a ranking just as much as objective data.

Table 4

Business Week 2014 MBA Ranking

\begin{tabular}{|c|c|c|c|c|c|c|}
\hline $\begin{array}{c}2014 \\
\text { Overall } \\
\text { Rank }\end{array}$ & $\begin{array}{c}2012 \\
\text { Overall } \\
\text { Rank }\end{array}$ & School & $\begin{array}{c}2014 \\
\text { Student } \\
\text { Survey } \\
\text { Rank }\end{array}$ & $\begin{array}{c}\text { 2014 Employer } \\
\text { Survey Rank }\end{array}$ & $\begin{array}{c}\text { 2014 Intellectual } \\
\text { Capital Rank }\end{array}$ & $\begin{array}{c}\text { Ranking } \\
\text { Index Score }\end{array}$ \\
\hline 1 & 6 & $\underline{\text { Duke (Fuqua) }}$ & 22 & 2 & 2 & 100.00 \\
\hline 2 & 3 & $\begin{array}{c}\text { Pennsylvania } \\
\text { (Wharton) }\end{array}$ & 18 & 1 & 22 & 98.97 \\
\hline 3 & 1 & $\underline{\text { Chicago (Booth) }}$ & 15 & 3 & 11 & 98.30 \\
\hline 4 & 4 & $\underline{\text { Stanford }}$ & 17 & 4 & 25 & 96.62 \\
\hline 5 & 13 & $\underline{\text { Columbia }}$ & 20 & 6 & 16 & 95.39 \\
\hline 6 & 21 & Yale & 7 & 8 & 19 & 95.31 \\
\hline 7 & 5 & $\underline{\text { Northwestern }}$ & 21 & 5 & 32 & 95.09 \\
\hline
\end{tabular}




\begin{tabular}{|c|c|c|c|c|c|c|}
\hline $\begin{array}{c}2014 \\
\text { Overall } \\
\text { Rank }\end{array}$ & $\begin{array}{c}2012 \\
\text { Overall } \\
\text { Rank }\end{array}$ & School & $\begin{array}{c}2014 \\
\text { Student } \\
\text { Survey } \\
\text { Rank } \\
\end{array}$ & $\begin{array}{l}2014 \text { Employer } \\
\text { Survey Rank }\end{array}$ & $\begin{array}{l}2014 \text { Intellectual } \\
\text { Capital Rank }\end{array}$ & $\begin{array}{l}\text { Ranking } \\
\text { Index Score }\end{array}$ \\
\hline 8 & 2 & Harvard & 25 & 7 & 8 & 92.86 \\
\hline 9 & 8 & Michigan (Ross) & 10 & 10 & 18 & 92.50 \\
\hline 10 & 11 & $\begin{array}{c}\frac{\text { Carnegie Mellon }}{\text { (Tepper) }} \\
\end{array}$ & 11 & 9 & 39 & 91.34 \\
\hline 11 & 18 & $\underline{\text { UCLA (Anderson) }}$ & 3 & 16 & 15 & 89.38 \\
\hline 12 & 17 & $\begin{array}{l}\text { North Carolina } \\
\text { (Kenan-Flagler) } \\
\end{array}$ & 6 & 13 & 13 & 88.34 \\
\hline 13 & 7 & Cornell (Johnson) & 5 & 22 & 3 & 87.50 \\
\hline 14 & 9 & MIT (Sloan) & 13 & 12 & 7 & 87.36 \\
\hline 15 & 12 & Dartmouth (Tuck) & 9 & 14 & 28 & 85.92 \\
\hline 16 & 15 & Indiana (Kelley) & 2 & 18 & 46 & 85.86 \\
\hline 17 & 24 & Maryland (Smith) & 1 & 51 & 6 & 84.53 \\
\hline 18 & 22 & Emory (Goizueta) & 14 & 17 & 17 & 83.28 \\
\hline 19 & 14 & UC Berkeley (Haas) & 4 & 34 & 9 & 83.04 \\
\hline 20 & 10 & Virginia (Darden) & 19 & 11 & 50 & 82.75 \\
\hline 21 & 28 & $\underline{\text { USC (Marshall) }}$ & 8 & 26 & 27 & 81.17 \\
\hline 22 & 16 & NYU (Stern) & 23 & 15 & 31 & 80.98 \\
\hline 23 & 19 & $\frac{\text { Texas at Austin }}{\text { (McCombs) }}$ & 28 & 20 & 14 & 78.62 \\
\hline 24 & 30 & $\begin{array}{l}\text { Georgetown } \\
\text { (McDonough) } \\
\end{array}$ & 16 & 29 & 43 & 75.98 \\
\hline 25 & 34 & Rice (Jones) & 29 & 31 & 12 & 73.97 \\
\hline
\end{tabular}

Table 5

Business Week MBA 2014 Ranking: Methodology

\begin{tabular}{|l|l|l|}
\hline Indicator & Percentage & Description \\
\hline Student Survey & $45 \%$ & $\begin{array}{l}\text { Meant to record what students thought of their } \\
\text { MBA programs. Graduating (Full-Time) students } \\
\text { were surveyed in partnership with Cambria } \\
\text { consulting (21,833 students). To be ranked schools } \\
\text { needed either } 30 \% \text { if its class and 25 students } \\
\text { respond to the survey. Questions dealt with: } \\
\text { Quality of academic offerings; quality of the } \\
\text { student body; school culture. }\end{array}$ \\
\hline
\end{tabular}




\begin{tabular}{|l|l|l|}
\hline Indicator & Percentage & Description \\
\hline Employer Survey & $45 \%$ & $\begin{array}{l}\text { Aimed to reflect how MBA programs prepare } \\
\text { graduates for the jobs they seek. To find recruiters, } \\
\text { schools were asked to list employers who hired } \\
\text { their students since 2012 (pool of 8,358 recruiters } \\
\text { at 4,931 companies). Recruiters were asked to rate } \\
\text { up to 10 schools (they had experience with in the } \\
\text { last 5 years). Employer score is based on two } \\
\text { components: Average rating by employers, and the } \\
\text { number of good ratings it received. }\end{array}$ \\
\hline Intellectual Capital & $10 \%$ & $\begin{array}{l}\text { Attempts to rate the level of research expertise at } \\
\text { each school's faculty. This is measured by counting } \\
\text { published articles in top-20 business journals from } \\
\text { 2009-2013. }\end{array}$ \\
\hline
\end{tabular}

\section{Conclusion and Implications for Research}

Rankings have become a representation of both the prestige and the influence that postsecondary institutions possess, particularly in the United States and China, and, as such, they are a key driver of institutional prestige and influence (Pusser \& Marginson, 2013). Since rankings reinforce the process of student stratification between colleges and universities and the concentration of resources and prestige in a very few institutions (Astin \& Oseguera, 2004), perhaps a larger issue is that rankings (specifically those by U.S. News) contribute to the formation of elites and add emphasis to individual wealth. If one extrapolates from this, it can be seen that although these notions are alive in almost everyone's lives through the concept of the American Dream. The lives and aspirations of the majority of individuals across the country are fairly different from these elites. Highly-ranked institutions attract elites or, at the very least, highly-prepared students from all over the world, and these institutions serve as platforms for networks of influence and possibilities. But does this mean that the mission of an institution that 
does not attempt to be a top-50-institution is any less worth it to the individual, the community, or the country?

Furthermore, most of the literature suggests a concern for for-profit companies that assign value to educational institutions (Bagwell, 2007; Bastedo \& Bowman, 2009; Ehrenberg, 1999; Luca \& Smith, 2013; Shin et al., 2011); therefore, it would be interesting to see whether the Department of Education (ED) would be willing to create a task force to create a ranking system (not just a ratings system) that would address many of the aforementioned issues, and thus, provide an official ranking that would come from the Department of Education. While this would not prevent outside companies from creating their own rankings, it would at least discredit them to a degree, and therefore allow students to have access to information the academic community can rally behind. Then, if students looked for other alternatives, then "Caveat Emptor." I only think this is a valid possibility to research because more and more institutions are posting a larger variety of rankings on their websites. Recently, Thomas Edison State University listed on its website that it is recognized as a top 20 business program in the nation for online education according to geteducated.com. While I am not questioning the validity of the ranking, I am questioning the fact that more ranking systems seem to be surfacing, and with this, as Luca and Smith (2013) state, students are the ones who are provided with selective information.

To conclude, I agree with Bastedo and Bowman's analysis (2010) that further research is needed as to the impact that rankings have on the field of higher education as a whole. Student behavior and organizational change have been well addressed by the research community over the last 20 years, but not the aforementioned impact. The present study advances the field by 
examining the somewhat uncharted territory regarding the impact of business school rankings on enrollment trends. Chapter III explains the data and methodology that were used. 


\section{Chapter III \\ METHODOLOGY}

This chapter explains the methodological approach used in the present which analyzed the U.S. News rankings of business schools. The approach taken, combined variables supported in theory and by research into a new evaluation method so as to address the research questions. The purpose of this study was to examine how variances in rankings affected enrollment trends at different business schools. The majority of research published thus far has focused on undergraduate rankings; therefore, this study provides insight into the decision-making of business schools as it pertains to the relationship of their ranking and their enrollment trends.

This study was guided by the following questions:

1. Is there a relationship between a one-unit change in the rankings over time and the enrollment at a specific institution?

2. As a specific business school's ranking varies, does the acceptance ratio / selectivity rate of the business school change too?

3. Has the quality of the students, as measured by their GPA and GMAT scores, changed in response to a one-unit change in the rankings?

4. Have the attitudes of others towards the business school, as measured by a change in the peer assessment score that these institutions receive year over year, changed as a result of the one-unit variation in the rankings?

These research questions will help guide whether there is a correlation between business schools' enrollment trends and the rankings, and whether business schools modify their patterns of behavior (as it pertains to the students they admit) in order to meet enrollment quotas; 
specifically, when comparing top-25 business schools with non-top-25 ones. If none of these questions yield statistically significant results, one can potentially question the validity of the ranking set as it pertains to enrollment trends, since a hypothesis would be that variations in rankings do not have implications for enrollment behaviors and quality of students. Thus, the rankings themselves would fall into question.

\section{Other Business Schools' Ranking Methodologies}

At the time of this writing there are nine different business school rankings in the US (U.S. News, Business Week, Forbes, the Financial Times, the Economist, America Economia, CNN Expansion, Business Insider, and the Quacquarelli Symonds Ranking). Each one of these rankings utilizes a different metric to determine the positions of the schools within the rankings.

\section{Forbes}

This ranking system is based on the return on investment achieved by graduates. Forbes surveys business school graduates in terms of their pre- and post- MBA salaries, career choice, and location. Forbes compares the alumni earnings in the first 5 years after graduation to their opportunity cost (what the cost of attending their business school of choice was, plus earnings lost in those years) in order to determine what Forbes labels the MBA gain. Schools are ranked based on this score (Badenhausen, 2015).

\section{Financial Times}

The rankings in the Financial Times takes a more "worldwide approach" than the others, since it attempts to evaluate "the world's best full-time MBA programs" (Financial Times, n.d). It includes the largest amount of criteria (see Table 6). 
Table 6

Financial Times 2014 Ranking: Methodology

\begin{tabular}{|c|c|c|}
\hline Indicator & Percentage & Description \\
\hline Weighted salary & $20 \%$ & $\begin{array}{l}\text { This is the average alumni salary three years after } \\
\text { graduation }\end{array}$ \\
\hline Salary increase & $20 \%$ & $\begin{array}{l}\text { The change between an alumni's salary before their } \\
\text { MBA and after }\end{array}$ \\
\hline Value for money & $3 \%$ & $\begin{array}{l}\text { This includes all the tuition, fees and monies not } \\
\text { earned while earning pursuing an MBA compared } \\
\text { with the salary earned today }\end{array}$ \\
\hline Career progress & $3 \%$ & $\begin{array}{l}\text { Changes in the career seniority of alumni before } \\
\text { their MBA and after it }\end{array}$ \\
\hline Aims achieved & $3 \%$ & $\begin{array}{l}\text { The level to which alumni have attained the goals } \\
\text { they set out for once they started an MBA career }\end{array}$ \\
\hline Placement success & $2 \%$ & $\begin{array}{l}\text { The effectiveness of an institution's "career } \\
\text { planning service" to support the student as rated by } \\
\text { the alumni }\end{array}$ \\
\hline $\begin{array}{l}\text { Employment three } \\
\text { months after } \\
\text { graduation }\end{array}$ & $2 \%$ & Self-Explanatory \\
\hline $\begin{array}{l}\text { Alumni } \\
\text { recommendations }\end{array}$ & $2 \%$ & $\begin{array}{l}\text { Calculated by looking a survey of alumni and their } \\
\text { responses to the question of the three schools from } \\
\text { which they would recruit MBA graduates }\end{array}$ \\
\hline Female faculty & $2 \%$ & $\begin{array}{l}\text { Percentage of female faculty; a ratio of } 50 / 50 \\
\text { receives the highest possible score }\end{array}$ \\
\hline Female students & $2 \%$ & $\begin{array}{l}\text { The percentage of full-time female students in the } \\
\text { MBA program }\end{array}$ \\
\hline $\begin{array}{l}\text { Women in the } \\
\text { board }\end{array}$ & $1 \%$ & $\begin{array}{l}\text { The percentage of female members in the business } \\
\text { school's advisory board }\end{array}$ \\
\hline International faculty & $4 \%$ & $\begin{array}{l}\text { Calculated based on the amount of faculty whose } \\
\text { citizenship differs from the country of employment }\end{array}$ \\
\hline $\begin{array}{l}\text { International } \\
\text { students }\end{array}$ & $4 \%$ & $\begin{array}{l}\text { Calculated based on the amount of current MBA } \\
\text { students whose citizenship is different from the } \\
\text { country where they study }\end{array}$ \\
\hline International board & $2 \%$ & $\begin{array}{l}\text { Percentage of board members whose citizenship } \\
\text { differs from the country where the business school } \\
\text { is based }\end{array}$ \\
\hline
\end{tabular}




\begin{tabular}{|c|c|c|}
\hline Indicator & Percentage & Description \\
\hline $\begin{array}{l}\text { International } \\
\text { mobility }\end{array}$ & $6 \%$ & $\begin{array}{l}\text { This is calculated based on the amount of alumni } \\
\text { who worked on different countries pre-MBA and } \\
\text { who work on different countries three years after } \\
\text { graduation }\end{array}$ \\
\hline Languages & $1 \%$ & $\begin{array}{l}\text { This represents the number of extra languages } \\
\text { required to complete the MBA program }\end{array}$ \\
\hline $\begin{array}{l}\text { Faculty with } \\
\text { doctorates }\end{array}$ & $5 \%$ & Self-explanatory \\
\hline $\begin{array}{l}\text { Full-Time doctoral } \\
\text { rank }\end{array}$ & $5 \%$ & $\begin{array}{l}\text { This represents the number of doctoral graduates } \\
\text { from each business school in the last three years; } \\
\text { extra points are awarded if the graduates take } \\
\text { positions at one of the top-50 MBA schools }\end{array}$ \\
\hline $\begin{array}{l}\text { Full-Time research } \\
\text { rank }\end{array}$ & $10 \%$ & $\begin{array}{l}\text { This represents the number of articles published by } \\
\text { the school's current full-time faculty in } 45 \text { selected } \\
\text { academic (and practitioner) journals. The number } \\
\text { of publications is weighted relative to the faculty's } \\
\text { size }\end{array}$ \\
\hline
\end{tabular}

(Palin, 2014)

\section{Table 7}

The Economist 2014 Ranking: Methodology

\begin{tabular}{|c|c|c|}
\hline Indicator & Percentage & Description \\
\hline $\begin{array}{l}\text { New Career } \\
\text { Opportunities }\end{array}$ & $35 \%$ & $\begin{array}{l}\text { Diversity of recruiters }(25 \%) \text { - This represents } \\
\text { the number of industries in which graduates } \\
\text { found jobs } \\
\text { - Percentage of alumni who are employed within } \\
\text { three months of graduating }(25 \%) \text { - Self- } \\
\text { explanatory } \\
\text { - Percentage of alumni who found jobs through } \\
\text { the business school's career services }(25 \%) \text { - } \\
\text { Self-explanatory } \\
\text { Student assessment of the business school's } \\
\text { career services ( } 25 \%) \text { - Whether the business } \\
\text { school's career services met the student's } \\
\text { expectations and needs }\end{array}$ \\
\hline
\end{tabular}




\begin{tabular}{|c|c|c|}
\hline Indicator & Percentage & Description \\
\hline $\begin{array}{l}\text { Personal } \\
\text { development and } \\
\text { educational } \\
\text { experience }\end{array}$ & $35 \%$ & 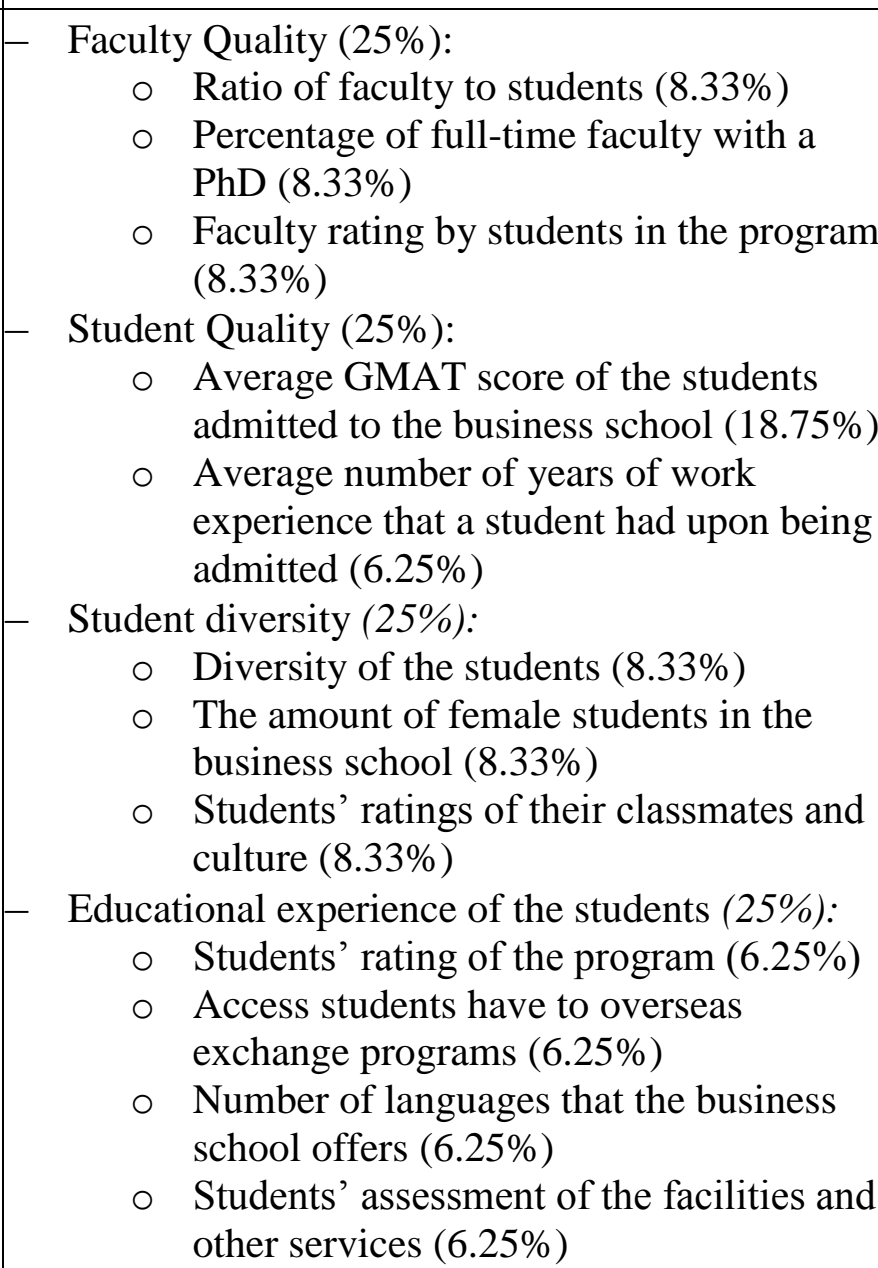 \\
\hline Salary & $20 \%$ & $\begin{array}{l}- \text { Salary change from pre- to post- MBA }(25 \%) \\
\text { - } \text { Post-MBA salary }(75 \%)\end{array}$ \\
\hline $\begin{array}{l}\text { Potential for } \\
\text { students to network }\end{array}$ & $10 \%$ & $\begin{array}{l}-\quad \text { Ratio of MBA alumni to current MBA students } \\
(33.33 \%) \\
-\quad \text { Number of overseas alumni chapters }(33.33 \%) \\
-\end{array}$ \\
\hline
\end{tabular}

(The Economist, 2014) 
Table 8

America Economia 2014 Ranking: Methodology

\begin{tabular}{|c|c|c|}
\hline Indicator & Percentage & Description \\
\hline Academic Quality & $40 \%$ & $\begin{array}{l}\text { This is represented by the percentage of full-time } \\
\text { faculty a business school has, and the student to } \\
\text { full-time faculty ratio that there is. Also, it } \\
\text { represents the quality of the part-time faculty as } \\
\text { determined by the last three jobs that the part-time } \\
\text { faculty have held }\end{array}$ \\
\hline $\begin{array}{l}\text { Publications by } \\
\text { Full-Time faculty }\end{array}$ & $15 \%$ & Self-explanatory \\
\hline $\begin{array}{l}\text { Internationalization } \\
\text { of the business } \\
\text { school }\end{array}$ & $20 \%$ & $\begin{array}{l}\text { By internationalized, the ranking looks at } \\
\text { agreements signed with other institutions, } \\
\text { accreditations, international campuses and } \\
\text { memberships to international organizations }\end{array}$ \\
\hline Alumni Network & $25 \%$ & Not explained in further detail \\
\hline
\end{tabular}

(America Economia, 2015)

\section{CNN Expansion}

The CNN Expansion ranking system allows students to modify the methodology as it best fits their needs. A student may choose to put a heavier emphasis on salary growth or on the number of full-time faculty who possess doctorates depending on personal preferences and the ranking will, based on these new weights, adjust the order accordingly. Table 9 shows the standard methodology listed on their website. It should be noted that CNN Expansion is an outlet designed to target the Latino population in the United States therefore, some of its weights are biased towards the aforementioned demographic. 
Table 9

CNN Expansion 2014 Ranking: Methodology

\begin{tabular}{|c|c|c|}
\hline Indicator & Percentage & Description \\
\hline GMAT Score & $20 \%$ & Self-explanatory \\
\hline $\begin{array}{l}\text { Number of Full- } \\
\text { Time faculty with } \\
\text { doctorates }\end{array}$ & $20 \%$ & Self-explanatory \\
\hline Salary growth & $25 \%$ & $\begin{array}{l}\text { This illustrates the mean starting salary after } \\
\text { graduation, as well as the amount of students hired } \\
\text { within three months of graduating. It also takes } \\
\text { into consideration an average of the students' pre- } \\
\text { and post- MBA salaries (the weights within this } \\
\text { category are not provided) }\end{array}$ \\
\hline $\begin{array}{l}\text { Diversity of the } \\
\text { student body }\end{array}$ & $10 \%$ & $\begin{array}{l}\text { This is considered both in terms of culture and } \\
\text { citizenship. Latino students in this ranking impact } \\
\text { the ranking favorably }\end{array}$ \\
\hline Experts assessment & $20 \%$ & $\begin{array}{l}\text { This is represented by three surveys which the } \\
\text { magazine sent to readers, administrators from } \\
\text { MBA schools and alumni from MBA programs }\end{array}$ \\
\hline $\begin{array}{l}\text { Number of } \\
\text { publications Full- } \\
\text { Time faculty } \\
\text { produce annually }\end{array}$ & $5 \%$ & Self-explanatory \\
\hline
\end{tabular}

(CNN Expansion, 2014)

\section{Business Insider}

Business Insider takes a different approach than the aforementioned ranking systems in that it merely uses a survey to rank all of the business schools. The survey is aimed at rating the reputation of the business school graduates from all around the world. Respondents could rank the graduates on a scale of 1 (poor) to 5 (excellent). Only responses from professionals who said they had experience hiring MBAs at least half the time are included. In case of a tie in total score, the number of excellent responses is used as a tiebreaker (Polland, 2014). 


\section{Quacquarelli Symonds (QS)}

The QS ranking is a ranking that mainly focuses on one thing, employability. The 2014/15 rankings have been tweaked so that employability accounts for $85 \%$ of the ranking, and a global faculty survey (newly introduced in 2015) accounts for the remaining $15 \%$ of the ranking. Employability is determined by an employer survey, which QS believes best captures the attributes that employers desire. QS asks employers to select the schools from which they would hire graduates. Employers are also asked to answer questions dealing with MBA recruitment trends, salaries and compensation, and global business ratings by region and specialization. Their answers make up the index of employer votes (Lavelle, 2015).

After reviewing all the business school rankings and methodologies, it was evident that there are two different approaches towards ranking business schools. Although both of these can overlap with one another, each of the approaches favors either a quantitative approach or a survey mechanism. An argument can be made that the first of these approaches is more objective, since it relies on quantifiable information--such as the average GMAT score--while the other is subjective since it relies on people's perceptions of the programs (i.e. faculty's opinions of other programs).

As mentioned, one approach attempts to look at as many criteria as possible, thus coming up with an elaborate ranking system; this is the case for The Financial Times, The Economist, CNN Expansion and America Economia. The other approach relies heavily on employer, student, and faculty surveys to determine what third parties believe about the business schools at hand. These results are then computed and the schools ranked. This is the case for Business Week, Business Insider, and Quacquarelli Symonds. Forbes is a special case, since only at one factor is 
examined (return-on-investment). While this approach would fit best in the first group due to its quantitative approach, it is the only one whose rankings are biased solely on one factor.

This leaves U.S. News. U.S. News can be seen as using a special ranking set, in that it merges both these approaches, since $40 \%$ of the value of a ranking comes from surveys (quality assessment) and the other $60 \%$ come from more quantitative criteria (e.g. GMAT, GPA, salary). This is the only ranking in which these are evenly distributed; thus providing a "best of both worlds" approach. Consequently, this was the dataset chosen for this analysis.

\section{Data}

The data selected for this study includes 8 years of rankings from U.S. News business school rankings, from 2008-2015. It needs to be noted that the U.S. News business school rankings are published a year in arrears; data is used from the year before. Therefore, the U.S. News 2015 Best Business School Rankings utilized data from applicants who tried to be admitted for the 2013-2014 academic year. Although different business schools have different application deadlines (some even claim that they have rolling applications), for the 2015/16 academic year most top-25 universities made admission decisions by December 2014. Duke (Fuqua), provided the earliest decisions by October (Byrne, 2014b). This means that, on average, students need to apply a year before they hope to be enrolled, if they want to be accepted to their top choice business school. It also means that the data provided in the 2015 ranking will be regarding the 2012 applicants. The 2015 rankings are based upon data for students who were enrolled that academic year (2014-2015), alumni who graduated or started their employment in May of 2014, and employers who hired graduates between May and August of 2014. Therefore, it is key to remember that this dataset, although it contains the 8 most recent years of data, 
actually included information that may be delayed as much as three years depending at what variable one looks at (see Figure 1).

Figure 1: 2015 Ranking: Timeline

\section{What the 2015 ranking shows}

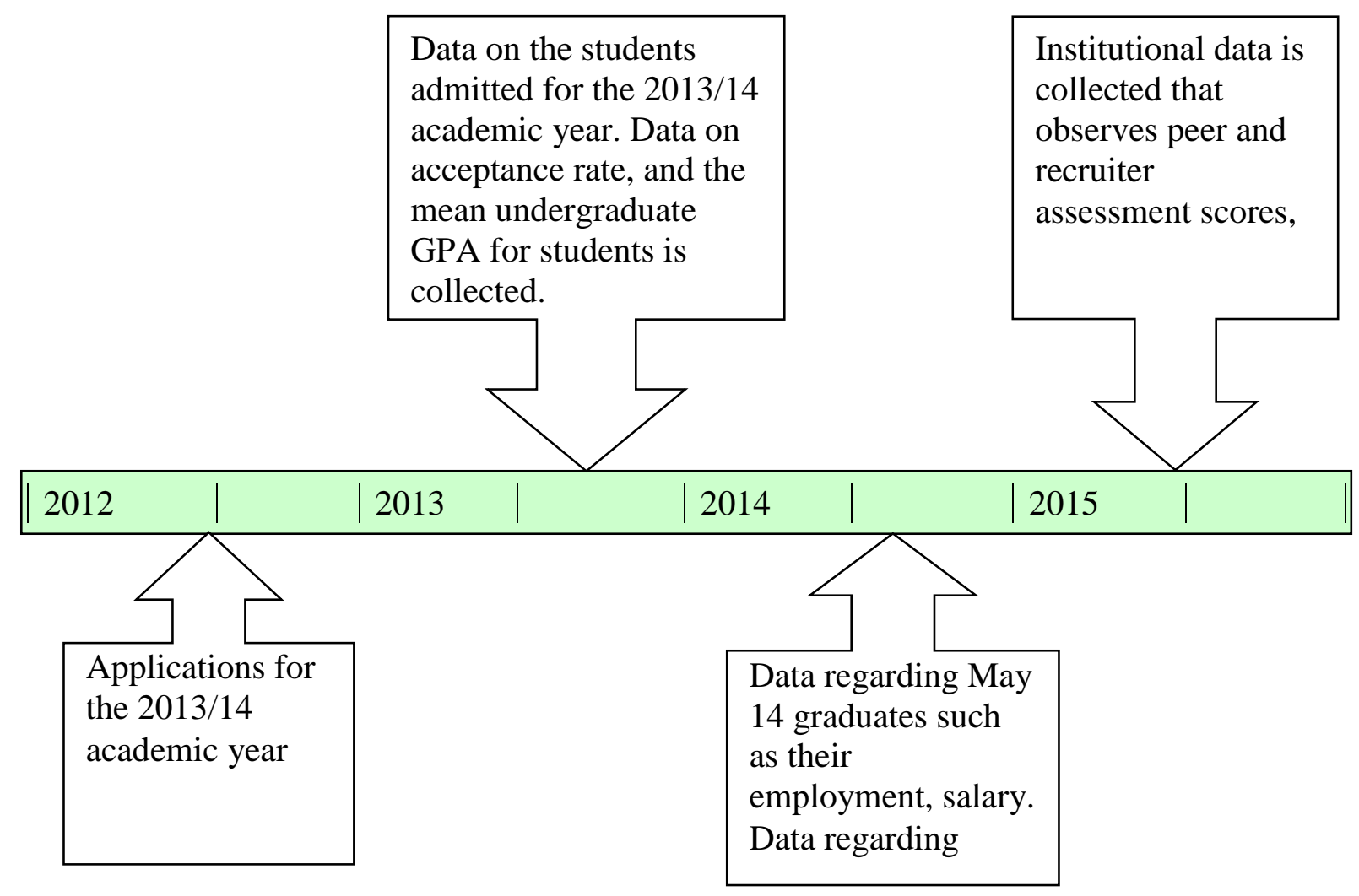

The data for this analysis was compiled by accessing different libraries and their information networks to acquire older editions of U.S. News magazines, as well as the purchase of the last years of the data directly from the U.S. News website in order to have access to the entire dataset. The reason for selecting U.S. News rankings over some of the other rankings is because U.S. News is considered one of the major sources for MBA rankings (Dichev 1999; 
Pleggenkuhle-Miles et al., 2013). Moreover, as Ehrenberg (2003) has pointed out, the U.S. News rankings are the gold standard for institutional rankings. As Griffith and Rask (2005) have pointed out: every year, every college administrator awaits the release of these rankings. And, as Bastedo and Bowman (2010) have stated, the U.S. News rankings and the study of their effects have become a small industry in higher education. Therefore, with some of the most prominent names in the institutional ranking industry I inferred that this was an appropriate dataset to utilize for the program-level rankings. Moreover, unlike other rankings, those of U.S. News allowed me the ability to disaggregate the data to the point necessary; thus, combining both the prestige of the ranking and the usefulness (for these purposes) of the data.

\section{Sample and Variables}

The sample for this study is the entire population of ranked business schools for the selected years. Over the period of time this data was gathered, the number of ranked business schools expanded from the top-50 in 2008 to the top-104 in 2015; therefore, only institutions that appeared in the ranking more than once were considered in order to properly conduct the methodology. If an institution only appeared one year in the rankings, while it was still part of

the study, the results were not analyzed, since the goal of this study was to measure the impact of variations in the rankings on institutions (and their other variables) from one year to another. In total, across the 8 years of data, 130 institutions were considered. The dataset consisted of the following variables:

1. Year: Self-explanatory.

2. Rank: The actual ranking a business school was assessed.

3. Tuition: The price of attending a specific business school.

4. Enrollment (Full-time): The current full-time enrollment of a business school. 
5. Average GMAT score: The average score that was attained by admitted fulltime students.

6. Acceptance rate: The amount of students per 100 who are admitted to the business school.

7. Average starting salary and bonus: The average starting salary and bonus of 2014 full-time graduates (in a business school master's program). Salaries are only based on graduates who reported data. The signing bonus is weighted by the number of graduates that reported a bonus.

8. Average undergraduate GPA: The CGPA (in their undergraduate degrees) of students enrolled into the business school full-time.

9. Peer Assessment score: How other institutions scored the business school (out of 5).

10. Recruiter Assessment score: How recruiters who hire MBA graduates scored the business school (out of 5).

11. Full-Time Graduates employed at graduation: Self-explanatory.

12. Full-Time Graduates employed 3 months after graduation: Self-explanatory.

\section{Data Analysis}

This study utilized cross-sectional time-series data (panel data) as to describe a causal relationship between the variables over time. Rankings, by nature, have a hierarchical structure; therefore, traditional linear models were not suitable to analyze these types of data because doing so would violate the assumption of independence (Raudenbush \& Bryk, 2002). Traditional linear regression models would have most likely allowed for autocorrelation in this dataset, since this data was being repeated over time and the values over the years can be related to one another. The data was a panel dataset, which provides multiple observations across 8 consecutive years, per business school. Panel data allowed the control of variables that changed over time, but not across individual institutions. Doing this, will account for individual heterogeneity. With panel data, variables can be included at different levels of analysis; thus, allowing for multilevel 
or hierarchical modeling (Bartels, 2008). A panel data analysis is a form of either longitudinal or cross-sectional data analysis, which allows for a two dimensional cross-section of data by which institutions can be observed across several time units (Baltagi, 1995). Panel data analysis can explain what, if any, variations transpired in the business schools throughout the years observed. The data used in the analysis technically contained no missing values, because the entire population of the U.S. News business school rankings for the selected years was considered; thus, all business schools were observed the same number of times. Nevertheless, the data in the set is an unbalanced set because we have missing data in terms of observations for certain years, due to the fact that some business schools entered the ranking 1 year and exited another or just been ranked for one year. Other institutions may have been ranked every year of the study. It should be noted that data was only available for the years in which the business schools were ranked. This study looked at the differences between top-25 and non-top 25 business schools, their interaction effects, and different responses to the research questions. Also, the reasoning for selecting the top-25 was that U.S. News printed a magazine edition of the rankings until 2010 but since then its online publication only lists the top-25 business schools when a person looks these rankings up in its first page; thus having to go to the next page in order to see the next grouping, and therefore, making the top-25 the default setting.

The equation for a panel regression with fixed effects is:

$$
\mathrm{Y}_{\mathrm{it}}=\beta_{1} \mathrm{X}_{\mathrm{it}}+\alpha_{\mathrm{i}}+\mathrm{u}_{\mathrm{it}}
$$

Where:

$\mathrm{Y}_{\text {it }}$ is the dependent variable (DV); where $\mathrm{i}=$ entity and $\mathrm{t}=$ time;

$\mathrm{X}_{\mathrm{it}}$ represents one independent variable (IV);

$\beta_{1}$ is the coefficient for that IV; 
$\alpha_{\mathrm{i}}(\mathrm{i}=1 \ldots \mathrm{n})$ is the unknown intercept for each entity ( $n$ entity-specific intercepts); and $\mathrm{u}_{\mathrm{it}}$ is the error term.

In this case though, because there are lags for certain characteristics, and an interaction effect is applied to the model, the equation is the following:

$$
Y_{i t}=\beta_{0 i}+\beta_{1 i} X_{1 i t(t-3)}+\beta_{2 i} X_{2 i t}+\beta_{3 i} X_{i t} X_{2 i t}+\ldots u_{i t}
$$

Where:

$\mathrm{Y}_{\text {it }}$ is the dependent variable (DV); where $\mathrm{i}=$ entity and $\mathrm{t}=$ time;

$\mathrm{X}_{1}$ represents students / institutional characteristics from a Non-Top-25 business school;

$\mathrm{X}_{2}$ represents students / institutional characteristics from a Top-25 business school;

$\beta_{1}$ is the coefficient for that IV;

$\alpha_{\mathrm{i}}(\mathrm{i}=1 \ldots \mathrm{n})$ is the unknown intercept for each entity ( $n$ entity-specific intercepts); and $\mathrm{u}_{\mathrm{it}}$ is the error term.

"In the case of time-series cross-sectional data the interpretation of the beta coefficients would be as $\mathrm{X}$ varies across time by one unit, $\mathrm{Y}$ increases or decreases by $\beta$ units" (Bartels, 2008)

\section{Merging and Cleaning of Data}

I used the unit identification number from IPEDS in order to merge all of the years of data into Microsoft Excel and SPSS with all of the variables in preparation for the statistical analysis. Institutional names were removed, and instead, the UnitID numbers from IPEDS were used. Finally, proxy values were assigned to all institutions that were not ranked during certain years, but were ranked in other years. The selected value for these instances was 110 because in 
none of the years studied did U.S. News rank more than 105 institutions. The number 110 fell outside the rankings in all of the years; thus, allowing it to be the proxy for not ranked.

\section{Limitations of the Study}

One of the main concerns with panel data is that it increases the possibility of violating the statistical assumptions needed to offer reliable analysis. The two main concerns are issues of heteroskedasticity and autocorrelation with the error terms. Other limitations of panel data are related to data collection (something not to be concerned with, since this study is looking to utilize the entire population); non-response in micro-panels, and cross-country dependency in macro-panels (Baltagi, 1995).

On a larger scale, there are limitations with the data itself in that U.S. News data is not verified: it is self-reported. Student responses may occur at different rates, and they may not reflect actual performance or quality. In fact, in some cases students may not respond to questions (especially as they pertain to salary), and a limitation for all programs in the sample and rankings of business schools. This issue of response rates is also pertinent for the quality assessment scores that were provided by the peer and recruiter surveys. While all of these introduce error, there is no reason to believe that they will change the results of the analysis.

\section{Descriptive Statistics}

An analysis of the descriptive statistics of the 130 business schools in the dataset allows the provides the following tables; the first (see Table 11), which shows means and standard deviations for variables across 8 years of data (it should be noted that 124 out of the 130 business 
schools where ranked in more than 1 year); the second (see Table 12), provides the same data, but for the year 2015 .

Table 10

Descriptive Statistics for the 8 years of data: Table 11 shows the descriptive statistics for years 2008 through 2015 (included)

\begin{tabular}{|l|c|c|c|c|c|}
\hline & Tuition (\$) & $\begin{array}{c}\text { Enrollment } \\
\text { (full-time) }\end{array}$ & $\begin{array}{c}\text { Average } \\
\text { GMAT } \\
\text { score (full- } \\
\text { time) }\end{array}$ & $\begin{array}{c}\text { Acceptance } \\
\text { rate (full- } \\
\text { time) (\%) }\end{array}$ & $\begin{array}{c}\text { Peer assessment } \\
\text { score (out of 5) }\end{array}$ \\
\hline Mean & 37,399 & 343 & 661 & 37 & 3.526 \\
\hline $\begin{array}{l}\text { Standard } \\
\text { Deviation }\end{array}$ & $10,771.4$ & 349.5 & 38.9 & 16.0 & 0.628 \\
\hline
\end{tabular}

$N=130$

Table 11

Descriptive Statistics FY15: Table 12 shows the descriptive statistics for the year 2015 only.

\begin{tabular}{|l|c|c|c|c|c|}
\hline & Tuition (\$) & $\begin{array}{c}\text { Enrollment } \\
\text { (full-time) }\end{array}$ & $\begin{array}{c}\text { Average } \\
\text { GMAT } \\
\text { score (full- } \\
\text { time) }\end{array}$ & $\begin{array}{c}\text { Acceptance } \\
\text { rate (full- } \\
\text { time) (\%) }\end{array}$ & $\begin{array}{c}\text { Peer assessment } \\
\text { score (out of 5) }\end{array}$ \\
\hline Mean & $40,091.4$ & 294 & 649.77 & 42.40 & 3.29 \\
\hline & & & & & 17.82 \\
\hline $\begin{array}{l}\text { Standard } \\
\text { Deviation }\end{array}$ & $11,861.51$ & 330.83 & 44.12 & & 0.64 \\
\hline
\end{tabular}

$N=104$

Table 11 shows that the mean acceptance ratio for ranked business schools between the years $2008-2015$ is $37 \%$, with a standard deviation of 16 . During this time, some of the most selective business schools had acceptance rates as low as $6.5 \%$ (e.g. Stanford) or $11 \%$ (e.g. 
Harvard); whereas the acceptance rates of other institutions were $77 \%$ (e.g. Pepperdine) and 60.6\% (e.g. Mississippi State).

Table 12 shows the mean acceptance rate for ranked business schools in the year 2015 was $42 \%$, with a standard deviation of 17 . Some of the most selective business schools (e.g. Stanford) had an acceptance rate of $6.5 \%$ in 2015; yet, other institutions, such as Northern Arizona University, had an acceptance rate of $89 \%$. With a ranking that has been expanded to include 104 business schools (from only 50 in 2008), a lesser selectivity ratio was expected.

Table 12 deals solely with the year 2015. For the year 2015 the variation in enrollment is very large. This can be attributed to the fact that some business schools were outliers. For example, for the year 2015 the enrollment of Harvard Business School was 1,851. Moreover, during the year 2015 there were four other business schools with enrollments larger than 1,000. Juxtaposed to this, there were 29 business schools in the ranking that had an enrollments under 100 students. This affects the variation in the dataset.

Table 11 shows the discrepancy in the tuition of the ranked business schools, with the mean being $\$ 37,399$ and the standard deviation being 10,771; approximately one third. The most expensive tuition was $\$ 61,152$, and it was for attending the Massachusetts Institute of Technology during the 2015 academic year. The lowest tuition in the sample was $\$ 8,700$ for Brigham Young University (Marriot) for the 2008 academic year. When these values are examined (see Table 12), one can see an increase in the tuition values, which is expected, since inflation and cost-of-living expenses are expected to affect these values, when compared with values that also take into consideration numbers from 8 years ago. That said, the mean for the variables in Table 12 is $\$ 40,091$ and the standard deviation 11,861 . 
Average GMAT is an interesting value to examine because as the rankings have expanded schools with arguably less selectivity standards have been included. Consequently, it can be seen that, as the ranking continued to expand, this value continued to decrease, thus making the dataset more variable. Table 11 shows a mean GMAT score of 661 with a standard deviation of roughly 39 for the population. However, as seen in Table 12 (for 2015) the GMAT average drops to approximately 650, yet the standard deviation increases to 44 .

The aforementioned explanation regarding the expansion of the rankings can also be used to explain the decrease in the peer selectivity scores, which decreased from 3.52 when looking at the entire dataset (see Table 11) to 3.29 when observing only 2015 (see Table 12).

Finally, it should be noted that after running a Hausman test for the data in all of the research questions, the results were always found to be statistically significant; therefore, it was determined that fixed effects were always preferred (over random effects). Moreover, year fixed effects were used to control for economic conditions and other aspects that may have affected all business schools in different years of the study.

\section{Summary}

This chapter explained the methodology used in the present research. A description of the U.S. News dataset was provided. In addition, the analytic procedure used to analyze the data and the limitations of the study were detailed. Chapter IV presents the results of the analysis. 


\section{Chapter IV}

\section{RESULTS}

As discussed in the previous chapters, the research questions focus on the relationship between business school rankings and the enrollment trends at those institutions. The results of the study are presented in this chapter with regard to each of the research questions. The results are presented to show the differences between top-25 and the non-top 25 business schools and how institutions in these groups react to the research questions. The reasoning behind this grouping, is that U.S News lists 25 business schools when one looks these rankings up online; therefore, making the top-25 the default setting.

\section{Research Question 1}

Is there a relationship between a one-unit change in the rankings (over time) and the enrollment at a specific institution?

Table 12: Research Question 1 - Results

$\underline{\text { Hausman Test }}$

\begin{tabular}{|l|l|l|}
\hline $\mathrm{X}^{2}=711.37$ & $\mathrm{df}=10$ & $\mathrm{p}$-value $<2.2 \mathrm{e}-16$ \\
\hline
\end{tabular}

Fixed Effects

\begin{tabular}{|c|c|c|c|}
\hline & Estimate & Std. Error & $\begin{array}{c}\text { Statistically } \\
\text { Significant }\end{array}$ \\
\hline (Intercept) & 313.7858 & 29.14855 & $*$ \\
\hline Rank & -0.0625 & 0.32262 & \\
\hline Top-25 & 0.4592 & 43.8478 & \\
\hline Rank*Top-25 & 0.5218 & 1.83461 & \\
\hline
\end{tabular}




\begin{tabular}{|l|l|}
\hline $\mathrm{R}^{2}=0.0910$ & Adjusted $\mathrm{R}^{2}=0.0731$ \\
\hline
\end{tabular}

The data for enrollment and the U.S. News business school rankings is outlined next. The mean enrollment for all business schools in the sample is 342.5. The mean enrollment for the top-25 business schools is 711 , whereas the enrollment for business schools outside of the top-25 is 180. Affecting this data are Harvard Business School, with a yearly enrollment of 1800, and Northern Arizona University (Franke) and West Virginia University, with yearly enrollments of 32 and 34 respectively.

It can be observed that, for top-25 schools, as rank improved by one rank (i.e. going from 10 to 9$)$ enrollment decreased by $0.46(0.52+-0.06)$. Yet, in non-top 25 schools, as ranking improved by one rank (i.e. going from 30 to 29 ) enrollment increased by 0.062 . Moreover, the net effect on enrollment for a top-25 institution when compared with a non-top 25 institution was a decrease of 0.52 ; however, these results were not statistically significant.

This suggests that, in terms of increasing enrollment, graduate business schools negligibly benefit from having a better position in the U.S. News rankings, since all the results in this study are not statistically significant. Consequently, for a business school dean, for example, who is looking to boost enrollment, trying to increase its position in the U.S. News ranking should not constitute a priority, as it is not likely to yield the desired result: Especially, if one considers how expensive it could be to boost an institution's position in the ranking.

The $R^{2}$ value, shows that $9.1 \%$ of the variation is explained by this model. The adjusted $R^{2}$ helps explain how after taking the number of covariates into account, this model would help explain $7.32 \%$ of the variation. 


\section{Research Question 2}

As a specific business school's ranking varies, does the acceptance ratio / selectivity rate of the business school change too?

Table 13: Research Question 2 - Results

$\underline{\text { Hausman Test }}$

\begin{tabular}{|l|l|l|}
\hline $\mathrm{X}^{2}=24.942$ & $\mathrm{df}=10$ & p-value $=0.0054$ \\
\hline
\end{tabular}

Fixed Effects

\begin{tabular}{|c|c|c|c|}
\hline & Estimate & Std. Error & $\begin{array}{l}\text { Statistically } \\
\text { Significant }\end{array}$ \\
\hline (Intercept) & 30.6226 & 2.2943 & $* * *$ \\
\hline Rank & 0.1734 & 0.0571 & * \\
\hline Top-25 & 0.3375 & 7.7668 & \\
\hline Rank*Top-25 & 0.1641 & 0.325 & \\
\hline
\end{tabular}

\begin{tabular}{|l|l|}
\hline $\mathrm{R}^{2}=0.1723$ & Adjusted $\mathrm{R}^{2}=0.1385$ \\
\hline
\end{tabular}

The data in terms of acceptance rates and U.S. News business school rankings cannot be considered definite. For top- 25 schools, acceptance rates went down by $0.34(0.16+.017)$ percentage points for every one-unit increase in the rank (from 4 to 3 ). When looking at non-top 25 institutions, with every one-unit change (from 45 to 44 ) acceptance rates went down by 0.173 percentage points.

As a result, it can be argued that as institutions rise in the rankings, they are able to become more selective in terms of the students they accept. Business schools inside the top-25, for each position they improve, decreased their acceptance rate by almost $0.4 \%$ This is a noticeable decrease when one considers that the average acceptance rate of all top- 25 business 
schools across 8 years was $25.5 \%$ Therefore, an increase of $0.337 \%$ represents an overall increase of $1.32 \%$ in the selectivity rate of a business school.

In terms of non-top 25 business schools, the mean acceptance rate was found to be $43.8 \%$; therefore 0.173 only represents an increase of $0.39 \%$ in the selectivity rates of non-top 25 business schools. The net effect of a top-25 institution when compared with a non-top 25 institution in terms of acceptance rate was an increase of $0.16 \%$; however, this was not found to be statistically significant.

It can be argued that if an administrator is trying to increase the selectivity rate of a business school, increasing one position, even while outside of the top-25, may not yield impactful results. Conversely, the findings suggest that as business schools fell in the ranking, they tended to increase their acceptance rates. This suggests that these institutions reached further into their applicant pools to maintain similar enrollment numbers.

The $R^{2}$ value shows that $17.23 \%$ of the variation is explained by this model. The adjusted $R^{2}$ helps explain how after taking the number of covariates into account, this model explains $13.86 \%$ of the variation.

\section{Research Question 3}

Has the "quality" of the students, as measured by their GPA and GMAT scores, changed in response to a one-unit change in the rankings?

\section{$\underline{\text { GPA }}$}

Table 14: Research Question 3 (GPA) - Results

$\underline{\text { Hausman Test }}$

\begin{tabular}{|l|l|l|}
\hline$X^{2}=20.485$ & $d f=10$ & $p$-value $=0.025$ \\
\hline
\end{tabular}


Fixed Effects

\begin{tabular}{|c|c|c|c|}
\hline & Estimate & Std. Error & $\begin{array}{c}\text { Statistically } \\
\text { Significant }\end{array}$ \\
\hline (Intercept) & 3.3870 & 0.0214 & $*$ \\
\hline Rank & -0.0020 & 0.0005 & $*$ \\
\hline Top-25 & 0.008 & 0.0069 & $*$ \\
\hline Rank*Top-25 & -0.006 & 0.4398 & \\
\hline
\end{tabular}

Signif. codes: ${ }^{\prime * * *}=p<0.001 \quad{ }^{\prime * *}=p<0.01 \quad{ }^{\prime *}{ }^{\prime}=p<0.05 \quad \because ’=p<0.1$

\begin{tabular}{l|l}
$R^{2}=0.0989$ & Adjusted $R^{2}=0.0795$
\end{tabular}

The data shows that as U.S. News business school rankings improved by one rank (e.g. 5 to 4) the GPA scores of applicants increased. For top-25 schools, the GPA scores increased by 0.008 points for every one-unit increase in the rank (from 4 to 3 ). When looking at non-top 25 institutions, GPA scores increased by 0.002 points per ranking increase (from 43 to 42 ). Both these results are statistically significant.

Consequently, one could argue that as institutions rise in the rankings they are able to accept "better prepared" students--as determined by their undergraduate GPAs--and become more selective about the students they accept. However, business schools inside the top-25 admitted students with an average undergraduate GPA of 3.4; therefore, an increase of 0.008 points per position that an institution rose can be considered underwhelming at best. The increase was 0.24 of a percentage point for each position they escalate.

This is more of an issue when considering non-top 25 business schools, since the mean GPA score for them was also found to be 3.4, but the increase found for a one unit change in the ranking (from 40 to 39) is one fourth that of the top-25 business schools. In the case of non-top 25 business schools, this increase represents 0.06 of a percentage point for each position that the 
institution escalates. The net effect on a top- 25 institution when compared with a non-top 25 institution in terms of the GPA of its applicants was an increase of 0.006 points per increase in the rankings.

It can be argued that if an administrator is trying to increase the undergraduate GPA of the full-time students admitted by the institution, an increase of one position will be a conscientious proposition, since the impact of a one unit increase in the rankings was not found to translate into a large change in the undergraduate GPA of the student population.

The $R^{2}$ value, showed that $9.89 \%$ of the variation is explained by this model. The adjusted $R^{2}$ explained how, after taking the number of covariates into account, this model explained $7.95 \%$ of the variation.

\section{GMAT}

Table 15: Research Question 3 (GMAT) - Results

$\underline{\text { Hausman Test }}$

\begin{tabular}{|l|l|l|}
\hline$X^{2}=15.007$ & $d f=10$ & $p$-value $=0.1318$ \\
\hline
\end{tabular}

Fixed Effects

\begin{tabular}{|c|c|c|c|}
\hline & Estimate & Std. Error & $\begin{array}{c}\text { Statistically } \\
\text { Significant }\end{array}$ \\
\hline (Intercept) & 685.767 & 3.4012 & $*$ \\
\hline Rank & -0.7310 & 0.0773 & $*$ \\
\hline Top-25 & -0.8969 & 10.511 & \\
\hline Rank*Top-25 & -0.1660 & 0.4398 & \\
\hline
\end{tabular}

Signif. codes: ${ }^{\prime * * * ’}=p<0.001 \quad$ ‘**’ $=p<0.01 \quad$ ‘*’ $=p<0.05 \quad \because ’=p<0.1$

$$
\begin{array}{l|l}
R^{2}=0.3447 & \text { Adjusted } R^{2}=0.2772
\end{array}
$$


The data for GMAT scores and U.S. News business school rankings cannot be considered definite. GMAT scores can range between 200 and 800, with two-thirds of the test takers scoring between 400 and 600 (GMAC). For top-25 schools, the GMAT scores went up by 0.897 points $(-0.16+-0.73)$, for every one-unit increase in the rank (from 4 to 3$)$; however, this increase was not found to be statistically significant. When looking at non-top 25 institutions, GMAT scores went up by 0.73 points per ranking increase (from 43 to 42 ), and this increase is statistically significant.

Consequently, the argument that as institutions rise in the rankings they will be able to accept "better prepared" students--as determined by their undergraduate GMAT scores--and therefore become more selective in terms of the students they accept, is only partly validated by the results of this study. For institutions inside the top-25, the study showed no statistical significance with the results. When considering non-top 25 business schools, the mean GMAT score was found to be 641 . Therefore, what kind of impact does an increase of 0.73 actually have? The net effect of a top-25 institution when compared with a non-top 25 institution in terms of its students' GMAT scores was found to be an increase of 0.17 points; however, this was not found to be statistically significant.

It can be argued that if an administrator is trying to increase the GMAT scores of the fulltime students admitted to an institution, increasing one position in the U.S. News ranking will not necessarily yield the desired results, since the impact of a one-unit increase in the rankings was not found to translate to a large change in the GMAT scores of the student population.

The $R^{2}$ value, showed that $34.48 \%$ of the variation is explained by this model. The adjusted $R^{2}$ helps explain how after taking the number of covariates into account, this model would help explain $27.72 \%$ of the variation. 


\section{Research Question 4}

Have the attitudes of others towards the business school, as measured by a change in the peer assessment score that these institutions receive year over year, changed as a result of the one-unit variation in the rankings?

Table 16: Research Question 4 - Results

$\underline{\text { Hausman Test }}$

\begin{tabular}{|l|l|l|}
\hline$X^{2}=15.007$ & $d f=10$ & $p$-value $=0.1318$ \\
\hline
\end{tabular}

Fixed Effects

\begin{tabular}{|c|c|c|c|}
\hline & Estimate & Std. Error & $\begin{array}{c}\text { Statistically } \\
\text { Significant }\end{array}$ \\
\hline (Intercept) & 3.6635 & 0.0399 & $*$ \\
\hline Rank & -0.0038 & 0.0006 & $*$ \\
\hline Top-25 & -0.8969 & 0.0811 & \\
\hline Rank*Top-25 & -0.0042 & 0.0034 & \\
\hline
\end{tabular}

Signif. codes: ' $* * * ’=p<0.001 \quad$ '**’ $=p<0.01 \quad$ ‘*’ $=p<0.05 \quad$ :’ $=p<0.1$

\begin{tabular}{|l|l|}
\hline$R^{2}=0.2713$ & Adjusted $R^{2}=0.2182$ \\
\hline
\end{tabular}

The data shows that as U.S. News business school rankings improved by one rank (e.g. 5 to 4) the peer assessment scores given to these business schools also increased. For top-25 schools, the peer assessment scores was found to go up by 0.008 points for every one-unit increase in the rank (from 4 to 3); however, this increase was not statistically. When looking at non-top 25 institutions, peer assessment scores were found to go up by 0.004 points per ranking increase (from 43 to 42), and this increase was found to be statistically significant.

Consequently, the argument that as institutions rise in the rankings they become better perceived by their peers (as determined by their peer assessment scores) has to be evaluated. For 
institutions inside the top-25, there was no statistical significance in the data. When considering non-top 25 business schools, the mean peer assessment score was 3.1, therefore, an increase of 0.004 points represents an increase of 0.13 percentage points in the overall score. The net effect on a top-25 institution when compared with a non-top 25 institution in terms of the peer assessment scores was found to be an increase of 0.004 points. This was not found to be statistically significant.

It can be argued that if an administrator is trying to increase the reputation of a business school with peers (as measured by the peer assessment scores), then increasing one position in the U.S. News ranking will not necessarily yield the desired result, since the impact of a one-unit increase in the rankings was not found to translate to a large change in the perception peers have of an institution.

The $R^{2}$ value showed that $27.13 \%$ of the variation is explained by this model. The adjusted $R^{2}$ explains how after taking the number of covariates into account this model explained $21.82 \%$ of the variation.

\section{Summary}

The purpose of this study was to try to determine whether there was a correlation between variances in business school rankings and these institutions' enrollment trends and practices at these institutions. This chapter attempted to answer the research questions that guided the study. The results presented in this chapter offered a statistical analysis which assisted towards answering the aforementioned questions, and while some of these answers were not found to be statistically significant, they did open the door to question the validity of the ranking set in regards to enrollment trends and practices. Chapter V provides further detail about the study and provides implications of the findings and directions for future research. 


\section{Chapter V}

\section{CONCLUSION}

The purpose of this study was to examine the effect that variances in business school rankings (specifically U.S. News) have on enrollment trends and practices. While this has not been the first study to try to examine these effects, it has been the first one to look at this phenomenon over the last 15 years and, consequently, the only one which has looked at the last 8 years of data (2008-2015). Furthermore, this study, unlike others, has attempted to answer questions that have dealt with both objective data (such as enrollment numbers or GMAT scores), as well as subjective data (such as peer assessment scores). Other studies often focused on either, but not both in one study. Moreover, most recent studies have tended to deal with undergraduate rankings, and often did not address graduate programs or graduate schools in general.

\section{Summary of Results}

What follows is a summary of the key outcomes from the present study as pertains to the research questions. First, this study provided results based on the placement of an institution inside the top-25 or not, as well as examined the interaction effect for those institutions inside the top-25 to show whether top-25 institutions responded differently than other programs, since they are more "visible." One consistent pattern found in the results is that for institutions ranked inside the top-25, the results were, more often than not, not statistically significant. In other words, there was no statistically significant correlation measured between the question at hand and variance in the U.S. News ranking. Another finding from the study was that even when a 
statistically significant result (at any level) was found, it often represented increases or decreases so negligible that they basically did not have much meaning. A reason for this could be that institutions inside the top-25 did not tend to vary from one year to another, and even if they did, mobility inside the top-25 was found to be more difficult than outside of it.

Still, an administrator needs to stop and determine what his or her role and agenda will be long- and short-term at the business school. If his or her role involves enrollment increase, then perhaps paying attention to the U.S. News ranking and devoting resources to ensure that the business school maintains its position in the ranking is not a sensible use of resources. However, if said administrator's goal is more oriented toward maintaining a degree of prestige (as measured solely by the ranking), or a metric not measured here, then perhaps, this would prove a more worthwhile endeavor.

The first question the model attempted to answer dealt with enrollment and how business school enrollment numbers were affected by the variance of the school in the U.S. News ranking. After running a Hausman test, it was determined that a fixed effects model was preferred over a random effects one. Enrollment proved not to be statistically significant when dealing with business schools neither inside nor outside the top-25. This kind of effect would make an administrator wonder whether this correlation (or lack thereof) is important enough for him / her to equate enrollment and position in the rankings; and thus, keep this in mind when determining long-term strategy for the business school.

The second question the model attempted to address was whether or not there was a correlation between the acceptance rates of these business schools and the variance in the positions they occupied in the U.S. News business school ranking. After running a Hausman test it was determined that a fixed effects model was preferred over a random effects one. In this 
case, the results yielded by institutions outside the top- 25 were found to be statistically significant, in that as their ranking increased, their acceptance rate went down by 0.173 (for each ranking change). In other words, an institution would need to improve almost six positions to see an increase of $1 \%$ in its acceptance rate. This type of escalation is most likely easier to accomplish when moving from a rank of 100 to 95, than when moving from a rank of 31 to 26. In any event, the results for top- 25 business schools and acceptance rates did not prove to be statistically significant.

The third question dealt with the "quality" of the students that business schools would accept, as measured by their undergraduate GPA and their GMAT scores, and how this was impacted by the variation of the institution in the U.S. News rankings. In both these cases, after running Hausman tests, it was determined that fixed effects models were preferred over random effects ones. GPA was the only measure that proved to be statistically significant for both top and non-top 25 business schools. In the case of business schools ranked inside the top-25, as their rankings increased the GPA of students admitted was found to increase by 0.008 points. When dealing with institutions outside the top-25, the variable of student GPA only saw an increase of 0.002 points. Once more, although both of these findings were statistically significant what is the measurable impact of a 0.008 increase in student GPA? If a school rank of 25 improved its position to a rank of 1, this would mean that its students' undergraduate GPA grades would increase by 0.2 points. In the case of a school ranked 95 , if it improved its position to 26 , this would mean that it would see an increase in the GPAs of the students it admits of 0.138 points.

The second part of the third research question examined GMAT scores. The examination of institutions outside the top-25 yielded statistically significant results, in that as their rankings 
increased the GMAT scores were found to increase by 0.731 (for each ranking change). As has been articulated previously, GMAT scores range from 200-800 with the mean score for all the schools under study outside the top- 25 being 641 . Therefore, an increase of 0.731 would only seem significant for those institutions making big jumps in the rankings. In other words, it would take a jump of 27 positions to see an increase of 20 points in the GMAT scores of the students. If an institution jumped from a rank of 100 to a rank of 26, then this would signify the largest possible jump, and it would amount to an increase of 54 points in the GMAT scores of its admitted undergraduates. It should be stated that the results for the top-25 business schools and GMAT scores were not found to be statistically significant.

The fourth and final question in this study addressed peer assessment scores and their reactions to the variations in the business school rankings. After running Hausman tests, it was determined that fixed effects models were preferred over random effects ones. Once again, it was found that institutions outside of the top-25 showed a statistically significant result in that, as their rankings increased, the peer assessment scores increased by 0.004 for each ranking change. Although this was found to be a statistically significant result, considering that peer assessment scores are graded on a 5.0 scale, what is the measurable impact of a 0.004 increase in the score for a business school? In the case of a school ranked 95th, if it moved up 69 positions to 26th, this would mean that it would see an increase in its peer assessment scores of 0.276 points.

\section{Implications of this Study}

This study was an empirical study for administrators regarding rankings and enrollment variables. However, the findings of this study have implications for many stakeholders in the higher education field; mainly, prospective business school students, researchers, and 
administrators. Business school rankings are used by many people as a source by many to determine which business school to attend, work at, or even to send their children. Thus, rankings are seen as a measure of prestige (Bastedo \& Bowman, 2011; Freid, 2005; Sweitzer \& Volkwein, 2009). The main goal of this study was to allow administrators to determine the impact that rankings have on their enrollment trends and practices and to assist them in effectively assessing how to best determine strategies to deal with the impact of the rankings of their institution. The findings in this study can assist those who make decisions based on multiple criteria, and not necessarily with the sole purpose of climbing positions in the rankings.

Business school administrators are pursuing better positions in the U.S. News ranking (Fee et al., 2005), since there seems to be an unspoken belief that the payoff for increasing expenditures in specific areas and climbing the rankings results in an increase in prestige, which ultimately turns into an increase in revenue. However, this study found that some of the areas strongly associated with revenue (i.e. enrollment) were not correlated with an increase in the U.S. News ranking. Moreover, even in cases where there was statistical significance associated with a specific metric and the ranking increase, business school administrators should consider the financial output versus the potential benefit. Therefore, it should be questioned whether there is a need for business school administrators to continue pursuing improved positions in the U.S. News ranking, assuming the ultimate goals of this are an increase in revenue and likely in enrollment. If an increase in revenue is the goal, and this is mainly accomplished via enrollment (as only few institutions can count on enough endowments or donors to offset tuition monies), then relying on an increase in the ranking does not seem like the best use of resources; especially, when one considers the amount of additional resources that are often needed to obtain an increase in the rankings. Between 1995 and 2002 the University of Connecticut invested 2.3 
billion dollars as a strategic decision to improve their position in the undergraduate rankings (Farrell \& Van der Werf, 2007) and even after this investment their position has recently dropped from 64 to 67 . This happened mainly because other institutions have also been trying to increase their positions in the rankings; also investing heavily to make this happen. Ultimately, while prestige is a nice "perk" for institutions, enrollment is a necessity. Wake Forest (Babcock) closed its full-time MBA program on October 22, 2014 due to declining enrollments and applications over several years (Byrne, 2014c).

An alternative to this ranking-based approach is what some business schools, such as the University of Virginia and UCLA, have done to offset declining state contributions. These business schools decided to become more self-supportive by pursuing a privatization that allowed them to operate with more latitude and gave them the ability to raise tuitions and enrollments at will (Rivard 2014; Zusman 2005). They gave up some monies in terms of state funds, but considered these lost monies an investment in terms of the abilities they gained by being able to operate more independently; if an institution was to devote resources to an approach (to increase revenue), this could also be considered as an alternative. It should be noted though that with this other approach, these institutions' reliance on enrollment also became more pronounced.

Something else to consider is that the results of this study differ substantially from the studies of the impact of U.S. News rankings on undergraduate institutions. As Bowman and Bastedo (2009) showed, "for all colleges and universities in the top-25, moving one place in the rankings yields a 1.4 increase in SAT scores, a $0.25 \%$ decrease in acceptance rates. The effects of the rankings are far less pronounced for those institutions ranked outside the top-25" (p.13). Monks and Ehrenberg (1999) found that "a one-unit increase in U.S. News ranking corresponded 
to a $0.4 \%$ decrease in acceptance rate, a $0.2 \%$ increase in yield, and a 2.8 -point increase in average SAT score”(p.2).

When we consider these results with the findings from the present study it can be seen how there does not seem to be a correlation between rankings, enrollment trends, graduate and undergraduate institutions. This is an area for further study.

\section{Suggestions for Future Research}

This study was another attempt to explain the relationship between rankings and institutional behavior; more specifically, this study examined enrollment trends. This study provides a basis for future research, and it offers possibilities of expanding it in the following ways. First, this research was limited to the U.S. News ranking, and there exists the possibility to integrate other ranking systems into the study for a more comprehensive approach. If not, a comparative analysis could be done that juxtaposes both U.S. News and another ranking system using data that examines the salary growth of students or the return on investment of the degree (MBA). Second, this study was limited to an 8-year time frame. While this was fairly comprehensive, a larger dataset could offer further validation of the results. Therefore, the present study could be replicated with an expanded number of years. Third, as years go by and the data becomes obsolete, this study should be repeated in order to update the existing information to reflect the most current information possible. Also, alternative definitions to certain terms could be used. In other words, measuring the attitudes of others towards the business schools by using the peer assessment scores could be changed to using the recruiter assessment scores or the amount of students hired at graduation. Also, an economic study that explores the salaries of students at graduation, as well as within 3 and 6 months of it, could be 
incorporated. Following this same idea, alumni donations could be tracked and could be incorporated into the study. As Monks and Ehrenberg (1999) stated, an improved ranking can lead to increase donations from proud alumni. It would be an interesting study to determine whether the prestige associated with these ranked institutions correlates with higher alumnigiving.

Finally, although this study has shown that many of the research questions examined in this study were statistically significant, the concept of causality still remains. Do the changes in the rankings actually drive the changes in the variables, or is it the change in the variables that actually drive the changes in the rankings? The model shows a correlation in the data, but does not show what drives the changes. It would take a qualitative study to determine what specifically drives the decision to enroll or not a certain number of students, to increase or decrease the selectivity rate, and other metrics mentioned in this study.

\section{Conclusion}

This study has attempted to bridge a gap in the literature found in terms of the U.S. News rankings and the institutional responses that occur as any given business school experiences a fluctuation in its rank. The model used can be of help to administrators and researchers who wish to better understand the repercussions of mobility in the rankings. This model was done with the last years of available data and was an empirical study. It should be emphasized that for the years for which the data in the study was derived there were not big changes in the methodology that U.S. News used; however, any changes that did occur were not data driven, but merely a value judgment at best. 
The goal of this study was to help others ascertain whether the amount of emphasis placed on the U.S. News rankings was warranted. Even in cases where a correlation was found between the ranking change and the variables measured, it would be at the discretion of each individual business school (administrator) to determine whether or not the reward is worth the expense. Yet, as business schools make the strategic choice of attempting to rise in the U.S. News rankings, they need to understand that the benefits of this ranking increase, at least from the standpoint of the questions posed for this study, may not necessarily be significant; and even when they are measurable, they may be so negligible that the costs associated with the strategic decision could potentially outweigh anything else. 


\section{References}

AACSB (n.d). Association to Advance Collegiate Schools of Business

Altbach, P. G. (2012). The globalization of college and university rankings. Change. 26-31.

Alter, M., \& Reback, R. (2014). True for your school? How changing reputations alter demand for selective US colleges. Educational Evaluation and Policy Analysis, 0162373713517934 .

America Economia (2015). Metodologia. America Economia. Retrieved from http://rankings.americaeconomia.com/mba2015/metodologias/

Argenti, P. (2000). Branding B-schools: Reputation management for MBA programs. Corporate Reputation Review, 3(2), 171-178.

Ashenfelter, M. (2010, May 4). Colleges refuse notable ranking survey. The Nation Magazine. Retrieved from http://www.thenation.com/article/colleges-refuse-notable-ranking-survey/

Astin, A. W., \& Oseguera, L. (2004). The declining "equity" of American higher education. The Review of Higher Education, 27(3), 321-341.

Badenhausen, K. (2015, September 9). The best business schools 2015: Behind the numbers. Forbes Business. Retrieved September 13, 2015. Retrieved from http://www.Forbes.com/

Bagwell, K. (2007). The economic analysis of advertising. Handbook of industrial organization, 3, 1701-1844.

Baltagi, B. (1995). Econometric analysis of panel data. Wiley. 
Bartels, B. (2008). Beyond "fixed versus random effects": a framework for improving substantive and statistical analysis of panel, time-series cross-sectional and multilevel data. The Society for Political Methodology, 1-43.

Bastedo, M. N., \& Bowman, N. A. (2010). US News \& World Report college rankings: Modeling institutional effects on organizational reputation. American Journal of Education, 116(2), 163-183.

Bastedo, M. N., \& Bowman, N. A. (2011). College rankings as an interorganizational dependency: Establishing the foundation for strategic and institutional accounts. Research in higher education, 52(1), 3-23.

Bastedo, M. N., \& Gumport, P. J. (2003). Access to what? Mission differentiation and academic stratification in US public higher education. Higher Education, 46(3), 341-359.

Bednowitz, I. (2000). The impact of the Business Week and US News \& World Report rankings on the business schools they rank. Cornell Higher Education Research Institute (CHERI), 6.

Berger, J. B. (2000). Organizational behavior at colleges and student outcomes: A new perspective on college impact. The Review of Higher Education. 23: 177-198.

Bowman, N. A., \& Bastedo, M. N. (2009). Getting on the front page: Organizational reputation, status signals, and the impact of US News and World Report on student decisions. Research in Higher Education, 50(5), 415-436.

Bowman, N. A., \& Bastedo, M. N. (2011). Anchoring effects in world university rankings: exploring biases in reputation scores. Higher Education, 61(4), 431-444. 
Brink, K. E., \& Smith, C. (2012). A comparison of AACSB, ACBSP, and IACBE accredited US business programs: An institutional resource perspective. Business Education \& Accreditation, 4(2), 1-15.

Byrne, J. (2014a, May 26). Why the MBA is now the most popular master's. Poets \& Quants. Retrieved from http://poetsandquants.com/

Byrne, J. (2014b, May 22). 2014-2015 MBA application deadlines at top business schools. Poets \& Quants. Retrieved from http://poetsandquants.com/

Byrne, J. (2014c, October 22). Wake Forest exits full-time MBA market. Poets \& Quants. Retrieved from http://poetsandquants.com/

Chade, H., \& Smith, L. (2006). Simultaneous search. Econometrica, 74(5), 1293-1307.

Clarke, M. (2002). Quantifying quality: What can the US News and World Report rankings tell us about the quality of higher education? Education Policy Analysis Archives, 10, 16.

CNN Expansion (2014). Metodologia mejores M.B.A. 2014. CNN Expansion. Retrieved from http://www.cnnexpansion.com/especiales/2014/03/05/metodologia-mejores-mbaglobales-2014

Corley, K.G., and Gioia, D.A. (1999) Reconciling scattered images: The consequences of reputation management for insider audiences. Paper presented at the 3rd International Conference on Corporate Reputation, Identity, \& Competitiveness, San Juan, PR.

Corley, K., \& Gioia, D. (2000). The rankings game: Managing business school reputation. Corporate Reputation Review, 3(4), 319-333. 
D'Aveni, R. A. (1996). A multiple-constituency, status-based approach to interorganizational mobility of faculty and input-output competition among top business schools. Organization Science, 7(2), 166-189.

Dearden, J. A., Grewal, R., \& Lilien, G. L. (2014). Framing the university ranking game: Actors, motivations, and actions. Ethics in Science and Environmental Politics, 13, 131-139.

Devinney, T., Dowling, G., Perm-Ajchariyawong, N., \& Dowling, C. G. (2006). The MBA rankings game. Australian Graduate School of Management, Working Paper.

Devinney, T., Dowling, G., \& Perm-Ajchariyawong, N. (2007). Business Week \& the Financial Times Business schools rankings: Similar but different. Australian Graduate School of Management, Working Paper.

Devinney, T., Dowling, G. R., \& Perm-Ajchariyawong, N. (2008). The Financial Times business schools ranking: What quality is this signal of quality? European Management Review, 5(4), 195-208.

Dichev, I. D. (1999). How good are business school rankings?. The Journal of Business, 72(2), 201-213.

Dichev, I. (2001). News or noise? Estimating the noise in the U.S. News university rankings. Research in Higher Education, 42(3), 237-266.

Dillon, M., McCaskey, P., \& Blazer, E. (2010). MBA Internships: More important than ever. Journal of Education for Business, 86(1), 44-49.

Diver, C. (2005, November). Is there life after rankings? The Atlantic Magazine. Retrieved from http://www.theatlantic.com/ 
Education Conservancy, The. (2007, May 10). The education conservancy. Retrieved from http://www.educationconservancy.org/presidents_letter.html

Ehrenberg, R. G. (2002). Reaching for the brass ring: The US News \& World Report rankings and competition. The Review of Higher Education, 26(2), 145-162.

Ehrenberg, R.G. (2005, fall) Method or Madness? Inside the U.S. News \& World Report College Rankings. Journal of College Admission. 189, 29-35.

Elsbach, K. D., \& Kramer, R. M. (1996). Members' responses to organizational identity threats: Encountering and countering the Business Week rankings. Administrative science quarterly, 442-476.

Espeland, W. N., \& Sauder, M. (2007). Rankings and reactivity: How public measures recreate social worlds. American Journal of Sociology, 113 (1) 1-40.

Farrell, E. \& M. van der Werf (2007, May 25). Playing the rankings game. Chronicle of Higher Education. Retrieved from http://chronicle.com/article/Playing-the-Rankings-Game/4451

Fee, C. E., Hadlock, C. J., \& Pierce, J. R. (2005). Business school rankings and business school deans: A study of nonprofit governance. Financial Management, 34(1), 143-166.

Feltovich, N., Harbaugh, R., \& To, T. (2002). Too cool for school: Signaling and countersignalling, RAND Journal of Economics, 33, (4), 630-649.

Fombrun, C., and Van Riel, C. (1997). The reputational landscape, Corporate Reputation Review, 1-16.

Freid, L. (2005). Reputation and prestige in American research universities: An exploration of the history of rankings and the increasing importance of student selectivity in perceptions 
of quality in higher education (Unpublished doctoral dissertation). University of Pennsylvania

Friedman, S. (2007, December 5). Putting a curious eye on a high school ranking system. New York Times. Retrieved from http://www.nytimes.com/

Giddens, A. (1976), New rules of sociological method. New York: Basic Books.

Gioia, D. A., \& Corley, K. G. (2002). Being Good versus Looking Good: Business School Rankings and the Circean Transformation from Substance to Image. Academy of Management Learning \& Education, 1(1), 107-120.

Golden, D. (2001a, May 29). Glass floor colleges reject top applicants, accepting only the students likely to enroll. Wall Street Journal. Retrieved from http://www.wsj.com/

Golden, D. (2001b, October 25). Some schools shun top grads; it's done to boost their 'yield rates' weeding out those least likely to enroll. Chicago Sun Times. Retrieved from http://chicago.suntimes.com/

Grewal, R., Dearden, J. A., \& Llilien, G. L. (2012). The university rankings game. The American Statistician, 64 (3), 232-237.

Green, C., \& Reingold, J. (1999). Business Week guide to the best business schools (Vol. 1). McGraw-Hill Companies.

Griffith, A., \& Rask, K. (2007). The influence of the U.S. News and World Report collegiate rankings on the matriculation decisions of high-ability students: 1995-2004. Economics of Education Review, 26, 244-255

Gumport, P. J., \& Bastedo, M. N. (2001). Academic stratification and endemic conflict: Remedial education policy at CUNY. The Review of Higher Education, 24(4), 333-349. 
Hall, R. (1992). The strategic analysis of intangible resources. Strategic

Management Journal, 13(2), 135-44.

Hazelkorn, E. (2007). The impact of league tables and ranking systems on higher education decision making. Higher Education Management and Policy, 19(2), 87.

Hazelkorn, E. (2009a). Impact of global rankings on higher education research and the production of knowledge. Centre for Social and Educational Research. Articles, 4, 1-21

Hazelkorn, E. (2009b). Rankings and the Battle for World-Class Excellence: Institutional Strategies and Policy Choices. Higher Education Management and Policy, 21(1), 1-23

Hazelkorn, E. (2015) Globalization and the reputation race in rankings and the reshaping of higher education: The battle for world class excellence. Palgrave MacMillan.

Hechinger, J. (2013, January 28). Bucknell University inflated SAT scores over 7 years. Bloomberg.com. Retrieved from http://www.bloomberg.com/

Higher Education Research Institute. (2007). College rankings and college choice: How important are college rankings in students' college choice process? Los Angeles, CA: Author.

Hoover, E. (2012, November 8). George Washington U. inflated class-rank data for more than a decade. Chronicle of Higher Education. Retrieved from http://chronicle.com/

Institute for Higher Education Policy (2007, April 18). Study: Institute for Higher Education Policy calls for global accountability of ranking systems to ensure quality and understanding across borders. Retrieved from http://www.ihep.org/press/newsreleases/study-institute-higher-education-policy-calls-global-accountability-ranking 
Jaschik, S. (2011, February 8). Anger over new rankings. Insider Higher Ed. Retrieved from https://www.insidehighered.com/

Jaschik, S. (2013, February 6). Can you verify that? Inside Higher Ed. Retrieved from https://www.insidehighered.com/

Jeon, Y; Miller, S., \& Ray, S. (2003). MBA program reputation: Objective rankings for students, employers and program administrators. University of Connecticut - Working Paper Series 2003, 28, 1-32

Jeon, Y., Miller, S. M., \& Ray, S. C. (2007, July). MBA program reputation and quantitative rankings: New information for students, employers, and program administrators. Employers, and Program Administrator.

Jin, G. Z., \& Whalley, A. (2007). The Power of Information: How do US News rankings affect the financial resources of public colleges? SSRN Working Paper Series.

Johnson, A. M. (2006). The destruction of the holistic approach to admissions: The pernicious effects of rankings. Indiana Law Journal, 81(1), 310-358

Karabel, J. (2005). The chosen. New York: Houghton Mifflin.

Keith, B. (2001). Organizational contexts and university performance outcomes: the limited role of purposive action in the management of institutional status. Research in Higher Education, 42(5), 493-516

Lederman, D. (2009, June 3). Manipulating, 'Er, influencing U.S. News. Inside Higher Education. Retrieved from http://www.insidehighered.com 
Lavelle, L. (2015). QS University Rankings Methodology. Quacquarelli Symonds. Retrieved from http://www.topuniversities.com/university-rankings-articles/world-universityrankings/qs-world-university-rankings-methodology

Lee, S. (2009, August 19). Reputation without rigor. Inside Higher Education. Retrieved from http://www.insidehighered.com

Luca, M. \& Smith, J. (2013). Salience in quality disclosure: Evidence from the US News college rankings. Journal of Economics \& Management Strategy, 22(1), 58-77.

Luca, M., \& Smith, J. (2015). Strategic disclosure: The case of business school rankings. Journal of Economic Behavior \& Organization, 112, 17-25.

Lytle, R. (2011, March 10). The ten most popular business schools. U.S. News and World Report. Retrieved from http://www.usnews.com/

MacKenzie, M. (2003). Exploring the desired outcome of an MBA education. Long Island Educational Review, 1-5.

March, J. G. (1991). Exploration and exploitation in organizational learning. Organization Science, 2, 71-87.

Martins, L. L. (1998). The very visible hand of reputational rankings in US business schools. Corporate Reputation Review, 1(3), 293-298.

Mathewson, T. G. (2015, April 15). A closer look at higher ed's love-hate relationship with rankings. Education Dive. Retrieved from http://www.educationdive.com/

McDonough, P. M., Antonio, A. L., Walpole, M., \& Perez, L. X. (1998). College rankings: Democratized college knowledge for whom? Research in Higher Education, 39, 513537. 
Meredith, M. (2004). Why do universities compete in the ratings game? An empirical analysis of the effects of the US News and World Report college rankings. Research in Higher Education, 45(5), 443-461.

Monks, J., \& Ehrenberg, R. G. (1999a). The impact of US News and World Report college rankings on admission outcomes and pricing decisions at selective private institutions. National Bureau of Economic Research, July 1999, 1-17

Monks, J., \& Ehrenberg, R. G. (1999b). US News \& World Report's college rankings: Why they do matter. Change: The Magazine of Higher Learning, 31(6), 42-51.

Moore, T. E. (2007, July/August). Repositioning the MBA. BizEd, 50-56. Retrieved from http://www.e-digitaleditions.com/i/58060-julyaugust2007/51

Morgeson, F. P., \& Nahrgang, J. D. (2008). Same as it ever was: Recognizing stability in the BusinessWeek rankings. Academy of Management Learning \& Education, 7(1), 26-41.

Morse, R. J., \& Flanigan, S. (2000). How we rank colleges. In America's Best Colleges 2001 (pp. 90-132). U.S. News \& World Report.

Murray, C. (2010, March). How many US MBA students are there? GMAC has the award winning answer. Graduate Management Admission Council. Retrieved from http://www.www.gmac.com/

Ortmans, L. (2015, April 12). MBA by numbers: Return on investment. The Financial Times. Retrieved from http://www.ft.com/

Palin, A. (2014, January 26). MBA Ranking 2014: Key and methodology. The Financial Times. Retrieved from http://www.ft.com/ 
Peters, K. (2007). Business school rankings: Content and context. Journal of Management Development, 26(1), 49-53.

Pettigrew, A. M., Cornuel, E., \& Hommel, U. (Eds.). (2014). The institutional development of business schools. OUP Oxford.

Pfeffer, J. \& Salancik, G. R. (2003). The external control of organizations: A resource dependence perspective. Stanford University Press.

Pleggenkuhle-Miles, E., Khoury, T. A., Deeds, D. L., \& Markoczy, L. (2013).

Exploring cognitive bias: Expert ratings of business schools. Management Decision, 51(9), 1905-1927.

Pike, G. R. (2004). Measuring quality: A comparison of U.S News rankings and NSSE benchmarks. Research in Higher Education, 45(2), 193-208.

Podolny, J. M. 1994. Market uncertainty and the social character of economic exchange. Administrative Science Quarterly, 39: 458-483.

Policano, A. J. (2007). The ranking game: and the winner is... Journal of Management Development, $26(1), 43-48$

Polland, J. (2014, August 4). Here's how we came up with our list of the world's best business schools. Business Insider. Retrieved from http://www.businessinsider.com

Pope, D. (2009). Reacting to Rankings: Evidence from America's Best Hospitals. Journal of Health Economics. Vol. 28, No. 6, 1154-1165.

Pusser, B., \& Marginson, S. (2013). University rankings in critical perspective. The Journal of Higher Education, 84(4), 544-568. 
Quacquarelli, N. (2007, February 19). B-School rankings lose their luster. Quacquarelly

Symonds. Retrieved from

http://www.topmba.com/mbanews/news_item/article/b_school_rankings_ lose their_lustre/

Raudenbush, S. W., \& Bryk, A. S. (2002). Hierarchical linear models: Applications and data analysis methods (2nd edition). Thousand Oaks, CA: Sage.

Ray, S. C. and Y. Jeon, (2003). Reputation and efficiency: A non-parametric assessment of America's top-rated MBA programs. Working Paper 2003-13, University of Connecticut. New Haven, CT.

Ray, S. C., \& Jeon, Y. (2008). Reputation and efficiency: A non-parametric assessment of America's top-rated MBA programs. European Journal of Operational Research, 189(1), 245-268.

Rindova, V. P., Williamson, I. O., Petkova, A. P., \& Sever, J. M. (2005). Being good or being known: An empirical examination of the dimensions, antecedents, and consequences of organizational reputation. Academy of Management Journal, 48(6), 1033-1049.

Rindova, V. P., Williamson, I. O. \& Petkova, A. P. (2010). Reputation as an intangible asset: reflections on theory and methods in two empirical studies of business school reputations. Journal of Management, 36(3), 610-19.

Rivard, R., (2014, June 30) Public to private MBA at UCLA. Inside Higher Ed. Retrieved from http://insidehighered.com/

Sauder, M., \& Lancaster, R. (2006). Do rankings matter? The effects of US News \& World Report rankings on the admissions process of law schools. Law \& Society Review, 40(1), 105-134. 
Safon, V. (2007). Factors that influence recruiters' choice of B-schools and their MBA graduates: Evidence and implications for B-schools. Academy of Management Learning \& Education, 6(2), 217-233.

Safon, V. (2009). Measuring the reputation of top US business schools: a MIMIC modeling approach. Corporate Reputation Review, 12(3), 204-28.

Safón, V. (2012). Can the reputation of an established business school change? Management in Education, 26(4), 169-180.

Schatz, M., \& Crummer, R. E. (1993). What's wrong with MBA ranking surveys? Management Research News, 16(7), 15-18.

Schoenfeld, G. (2015) 2015 MBA.com prospective students survey report. Graduate Management Admission Council. Retrieved from http://www.gmac.com/

Shin, J. C., Toutkoushian, R. K., \& Teichler, U. (2011). University rankings: Theoretical basis, methodology and impacts on global higher education (Vol. 3). Springer Science \& Business Media.

Simon, R. (2013, January 6). For newly minted MBAs a smaller paycheck awaits. The Wall Street Journal. Retrieved from http://www.wsj.com

Snider, S. (2015, August 4). Ten MBA programs where international students are the majority. U.S. News and World Report. Retrieved from http://www.usnwr.com/

Staff (2014). About The Lumina Foundation. Retrieved from www.luminafoundation.org

Stahl, M. J., Leap, T. L., \& Wei, Z. Z. (1988). Publication in leading management journals as a measure of institutional research productivity. Academy of Management Journal, 31(3), 707-720. 
Standifird, S. (2005). An Investigation on the U.S. NEWS Rankings Corporate Reputation Review, 6(3), 233-244.

Stevens, M. L. (2007). Choosing a class: College admissions and the education of elites. Cambridge, MA: Harvard University Press.

Strauss, V. (2007, August 17). U.S. News's college rankings face competition and criticism. The Washington Post. Retrieved from http://www.washingtonpost.com/

Stuart, D. L. (1995). Reputational rankings: Background and development. New directions for institutional research, 1995(88), 13-20.

Stuart, T. (2000). Interorganizational alliances and the performance of firms: A study of growth and innovation rates in a high-technology industry. Strategic Management Journal, 21: $791-811$

Stuart, T. E., Hoang, H., \& Hybels, R. C. (1999). Interorganizational endorsements and the performance of entrepreneurial ventures. Administrative Science Quarterly, 44(2), 315349.

Sweitzer, K., \& Volkwein, J. F. (2009). Prestige among graduate and professional schools: Comparing the US News' graduate school reputation ratings between disciplines. Research in Higher Education, 50(8), 812-836.

The Economist (2014). Methodology. The Economist. Retrieved from http://www.economist.com/whichmba/methodology-2014

The White House (2014). College Scorecard. U.S. Department of Education's College Affordability and Transparency Center. Washington, DC 
Thomas Edison State University (n.d). Thomas Edison State University. Retrieved from http://www.tesu.edu/

Thompson, N. (2000). How US News mismeasures higher education and what we can do about it. Washington Monthly. Washington, DC. Retrieved from http://www.washingtonmonthly.com/features/2000/009/thompson.htm

Thurman, P. W., \& Efimova, I. (2014). Use of rankings to improve global competitiveness of Russian's higher education institutions and technology exports. Life Sci J, 11(11), 285289.

Tracy, J., \& Waldfogel, J. (1997). The best business schools: A market-based approach. Journal of Business, 70(1), 1-31.

Trieschmann, J. S., Dennis, A. R., Northcraft, G. B., \& Nieme, A. W. (2000). Serving constituencies in business schools: MBA program versus research performance. Academy of Management Journal, 43(6), 1130-1141.

Tyson, G. (2001). A look behind the numbers. Selections: The Magazine of the Graduate Management Admission Council, 1(2), 8.

Usher, A. (2012, March 19). The Times Higher Education Research Rankings, Retrieved from http://higheredstrategy.com/the-times-higher-education-research-rankings/

USNEWS.com. (2015). Business school rankings methodology (2015). Retrieved from http://www.usnews.com/

USNEWS.com. (2008 through 2015). - Best business schools (2008 through 2015). Retrieved from http://www.usnews.com/ 
Vaccaro, A. (2014, May 22). Study: M.B.A. Now most popular master's degree. Boston.com. Retrieved from http://www.boston.com/business/personal-finance/2014/05/22/studynow-most-popular-master-degree/D2qggEZ50ZSz2irbFC9eCM/story.html

Van Vught, F. (2008). Mission diversity and reputation in higher education. Higher Education Policy, 21(2), 151-174.

Vidaver-Cohen, D. (2007). Reputation beyond the rankings: A conceptual framework for business school research. Corporate Reputation Review 10 (4), 278-304

Volkwein, J. F., \& Sweitzer, K. V. (2006). Institutional prestige and reputation among research universities and liberal arts colleges. Research in Higher Education, 47(2), 129-148.

Wuorio, J. (2001, fall). The impact of the rankings: multiple perspectives. Selections, Santa Monica 1(2), 26-37.

Webster, D. S. (1986). Academic quality rankings of American colleges and universities. Springfield, IL: Charles C. Thomas, Publisher.

Yeaple, R. N., Johnston, M. W., \& Whittingham, K. L. (2009). Measuring the economic value of pre-MBA work experience. Journal of Education for Business, 85(1), 13-20.

Zusman, A. (2005). Challenges facing higher education in the twenty-first century. American higher education in the twenty-first century: Social, political, and economic challenges, 2, 115-160. 